Article

\title{
Simulation and Analysis of Land Use Changes Applying Cellular Automata in the South of Quito and the Machachi Valley, Province of Pichincha, Ecuador
}

\author{
René Ulloa-Espíndola ${ }^{1}$ and Susana Martín-Fernández ${ }^{2, *(D)}$ \\ 1 ETSI Agronómica, Alimentaria y de Biosistemas, Universidad Politécnica de Madrid, \\ Ciudad Universitaria sn, 28040 Madrid, Spain; rene.ulloae@alumnos.upm.es \\ 2 ETSI Montes, Forestal y del Medio Natural, Universidad Politécnica de Madrid, Ciudad Universitaria sn, \\ 28040 Madrid, Spain \\ * Correspondence: susana.martin@upm.es
}

Citation: Ulloa-Espíndola, R.;

Martín-Fernández, S. Simulation and

Analysis of Land Use Changes

Applying Cellular Automata in the South of Quito and the Machachi

Valley, Province of Pichincha,

Ecuador. Sustainability 2021, 13, 9525.

https://doi.org/10.3390/su13179525

Academic Editor: Andrea Catorci

Received: 24 June 2021

Accepted: 18 August 2021

Published: 24 August 2021

Publisher's Note: MDPI stays neutral with regard to jurisdictional claims in published maps and institutional affiliations.

Copyright: (c) 2021 by the authors. Licensee MDPI, Basel, Switzerland. This article is an open access article distributed under the terms and conditions of the Creative Commons Attribution (CC BY) license (https:/ / creativecommons.org/licenses/by/ $4.0 /)$.

\begin{abstract}
Rapid urban growth has historically led to changes in land use patterns and the degradation of natural resources and the urban environment. Uncontrolled growth of urban areas in the city of Quito has continued to the present day since 1960s, aggravated by illegal or irregular new settlements. The main objective of this paper is to generate spatial predictions of these types of urban settlements and land use changes in 2023, 2028 and 2038, applying the Dinamica EGO cellular automata and multivariable software. The study area was the Machachi Valley between the south of the city of Quito and the rural localities of Alóag and Machachi. The results demonstrate the accuracy of the model and its applicability, thanks to the use of 15 social, physical and climate predictors and the validation process. The analysis of the land use changes throughout the study area shows that urban land use will undergo the greatest net increase. Growth in the south of Quito is predicted to increase by as much as 35\% between 2018 and 2038 where new highly vulnerable urban settlements can appear. Native forests in the Andes and forest plantations are expected to decline in the study area due to their substitution by shrub vegetation or agriculture and livestock land use. The implementation of policies to control the land market and protect natural areas could help to mitigate the continuous deterioration of urban and forest areas.
\end{abstract}

Keywords: land use change; cellular automata; Quito; native forest; urban land use; rural land use

\section{Introduction}

Human activity has generated land use change for centuries, shaping the territory and exploiting natural resources [1]. One of the uses with the highest impact on ecosystems is urban land use. The task of managing urban growth has increased in both scope and complexity, as today more than half the world's population lives in cities. These cities are expected to absorb 72\% of the future growth of the world's population [2] by 2050 [3]. Globally, urban cover is expanding at twice the rate of the global population growth due to rapid urbanization [4]. Urban land use increased from 0.6 million $\mathrm{km}^{2}$ in 2000 to $0.7-0.9$ million $\mathrm{km}^{2}$ in 2010, with projections of 1.2 million $\mathrm{km}^{2}$ by 2050 [5]. More than 5.87 million $\mathrm{km}^{2}$ of land have a positive probability $(>0 \%)$ of being converted to urban areas by 2030 [4]. Population growth and rural-to-urban migration are the principal drivers of this sharp surge [6].

Although this urban growth represents an important opportunity, according to the Sustainable Development Goals SDG 11, the aim of urban development should be to maximize benefits for the population and make cities inclusive, safe, resilient and sustainable, while minimizing both economic and environmental costs $[2,7,8]$.

However, rapid urban growth has historically led to changes in land-use patterns and the degradation of natural resources and the urban environment. It drives habitat loss [9], 
with impacts on ecoregions, rare species and protected areas. It also generates biodiversity degradation [10], with a loss of up to $40 \%$ of the species in some of the most biologically diverse areas around the world [11], produces changes in Earth's processes such as the water cycle [12] and produces significant increase in carbon emissions due to the removal of vegetation, the use of impervious surfaces and greater usage of local fossil fuel [13].

While considerable urban expansion will still occur in more-developed countries, most of this growth will take place in developing countries $[5,7,14]$, which are the least able to manage its negative implications $[8,15,16]$.

Latin America has been urbanized at a considerably faster rate than North America and Europe, although somewhat more slowly than Africa and Asia. In 2000, a similar degree of urban land cover was reached in Central and South America in half the time as in North America for the same year [17]. It is expected that $83 \%$ of the population of Latin America will live in cities by 2030 and up to $90 \%$ by 2050 [18]. More than $85 \%$ of this urban population lives in Argentina, Brazil, Chile, Colombia, Ecuador, Mexico, Perú and Venezuela, whose main cities have followed a similar evolution since their foundation in the 16th and 17th centuries to the present day [17]. Within these countries, it is worth highlighting those whose major cities are in the Andes or nearby, such as Quito (Ecuador), Bogota (Colombia), Santiago de Chile (Chile), or near a mountainous area like Caracas (Venezuela). Other important but less populated cities such as La Paz (Bolivia) or Cuzco (Peru) are in the Andes, at $3500 \mathrm{~m}$ asl and $3399 \mathrm{~m}$ asl, respectively. In terms of urban growth, the industrialization process between 1930 and 1970 was responsible for the rapid modernization of most Latin American countries and their extraordinary rural-urban population migration. From the 1980s to present day, they have followed a new economic model that includes structural adjustments such as de-industrialization, the growth of informal sectors and a rise in urban poverty. Until the present day, these urban areas have been distinguished by a much higher population increase in the peripheries than in the central nucleus, which are usually inhabited by the poor [17]. The challenge for policy makers is the sustainable management of these peripheral zones.

The development and urban transformation of the city of Quito (Ecuador) began in the 1960s after the expansion of oil exploitation in Ecuador, and in turn fueled the growth of communications and infrastructures. This development led to land use changes in the outskirts of Quito and in the surrounding valleys (Machachi, Pomasqui, Tumbaco, Los Chillos) that interconnect all these outlying areas $[19,20]$. In spite of the territorial planning legislation (the code of territorial organization, autonomies and decentralization for organizing the competencies of regional, provincial, cantonal, parochial and decentralized autonomous governments; the law of territorial planning, use and management of the land that establishes the principles and rules that govern the territorial planning, use and management of urban and rural land; the development and land management plans at the canton level and the law on the conservation of forestry, wildlife and natural areas), the uncontrolled growth of urban areas has continued to the present day, aggravated by illegal or irregular new settlements in the city's periphery. This paper defines illegal settlements as houses built on land by force or without the consent of the landowner, while irregular settlements are houses built by the landowner or another person with the owner's consent but without any technical regulation and/or municipal authorization, contravening the law. This pressure on the territory has led to the sacrifice of land with agricultural or forest potential, converting rural land into urban land and displacing crop and livestock areas to mountain slopes or to less fertile areas, leading to the loss of the social and environmental function of the land due to unsustainable land use policies [21]. A better understanding of the main drivers of forest loss requires monitoring of changes in forest cover at a small geographical scale in these areas [22].

Technologies for the simulation of territorial development have been developed to assure sustainable land use in the future. These technologies must combine environmental dynamics and human behavior to understand land use dynamics and identify future management activities, infrastructure demands and environmental changes, and are nec- 
essary to help policy decision-makers ensure the sustainable development of land use changes [23-28]. There are multiple modelling approaches to simulate land use changes. Some models such as SERGoM [29] and CLUE (Conversion of Land Use and its Effects) [30] were designed to determine changes in the spatial pattern at the regional or national scale, while other models like SLEUTH predict future LULC change on the basis of the behavioral change in land use at any scale [31]. Models with a more specialized approach include GEOMOD [32] and Land Use and Carbon Scenario Simulator, LUCAS [33], which not only obtains changes in land use cover but also their impact on forest cover and carbon dynamics respectively.

Cellular automata (CA) and the Markov model have important advantages in the simulation of land use changes and city growth. CA is a collection of regular cells on a geolocated grid that model space, and in which each cell has a specific state. CA mathematically obtains patterns based on a set of rules for dynamic systems, so cells evolve changing their states, according to a specific transition rule that simulates complex systems such as land use changes [24,34-37].

These models establish a transition potential for land uses depending on several variables: The capacity of the territory to host different land uses, accessibility, and a control factor for the land use neighborhood. This neighborhood factor represents the potential of change of a unit of territory depending on the attraction/repulsion effect exerted by the uses of the adjacent territory units.

Models based on artificial neural network (ANN) and Markov chain (MC) are amongst the best for estimating future land change transitions [38]; for instance, hybrid models based on multi-layer perceptron models and Markov chain can deliver accurate land use change transitions [39].

The modelling process in this study was performed with the geo-technological tool of the environmental modelling program Dinamica EGO. Dinamica EGO models use combinations of map algebra, cellular automata techniques and tabular data manipulation to represent complex socioeconomic and environmental systems. The transition probability maps are based on the weight of evidence and genetic algorithm methods and simulate landscape dynamics using both Markov chain matrices to determine the quantity of change and a cellular automata approach to reproduce spatial patterns [40-42]. According to Mas et al. [43], the Dinamica EGO tool is superior to other programs used for modelling changes in land use coverage due to its flexibility and its possibility of interacting with other tools, so it allows the development of sophisticated models. The user can create parts of a model (submodels) using the $\mathrm{R}$ and Python programming language and then reuse them. Dinamica EGO also provides system and local submodels [42]. This software has been widely used by the scientific community in various studies associated with modelling processes related to deforestation in tropical environments [44-46], urban growth $[47,48]$ and land use changes $[49,50]$, among others. No previous works have been found on the simulation with CA of the future growth of Quito and land use change in its area of influence.

The large cities of the Andes have similar characteristics, with a combination of legally urbanized zones and informal and illegal settlements.

The a priori knowledge of the changes in these zones and the identification of the possible urban-planning and environmental challenges would make it possible to define policies to adapt to future needs. The aim of this work was therefore to estimate and analyze the changes in land uses in a reference city, Quito, which presents these two types of urban zones. This was done by generating spatial predictions of changes in land use based on cellular automata and multivariable evaluation in 2023, 2028 and 2038 in the Machachi Valley between the south of the city of Quito and the rural localities of Alóag and Machachi.

This paper is organized as follows: Section 2 presents a brief description of the study area. We then explain the CA model and the data used in Section 3. Sections 4 and 5 
describe and discuss the results obtained by applying the proposed methodology in the Quito area. Finally, the conclusions drawn from our work are explained in Section 6.

\section{Study Area}

The study area covers $881.61 \mathrm{~km}^{2}$ and is located in the south of the city of Quito, in the Machachi Valley, district of Mejía, province of Pichincha $\left(9536 \mathrm{~km}^{2}\right)$, Ecuador (see Figure 1). This region contains three main urban localities: Part of Quito city (southern sprawl), Machachi and Alóag, which are $55 \mathrm{~km}$ far from Quito. It is surrounded by two nature reserves, the Pasochoa volcano and the Toachi-Pilaton protected area, the foothills of the Ilalo volcano and Los Chillos Valley and the mountains of Atacazo and Rumiñahui that belong to Quito, Rumiñahui and Mejía cantons (municipalities), with $4183 \mathrm{~km}^{2}, 139 \mathrm{~km}^{2}$ and $1476 \mathrm{~km}^{2}$, respectively (see Figures 1 and 2).
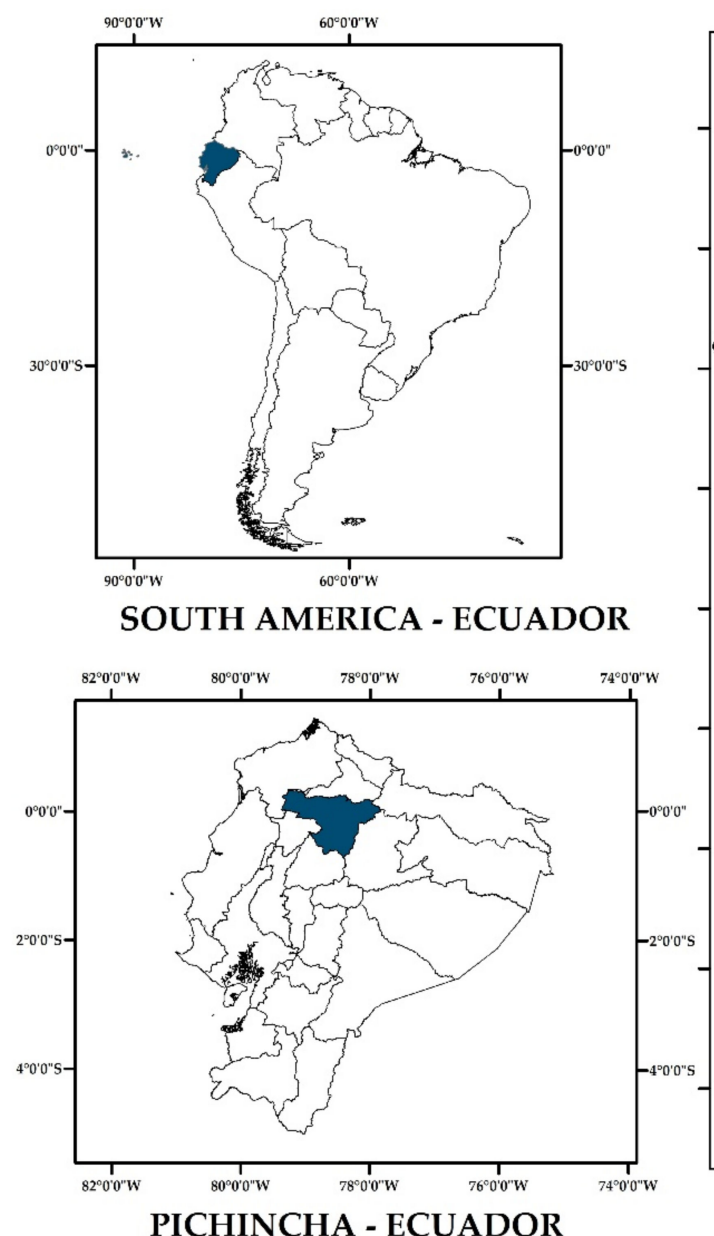

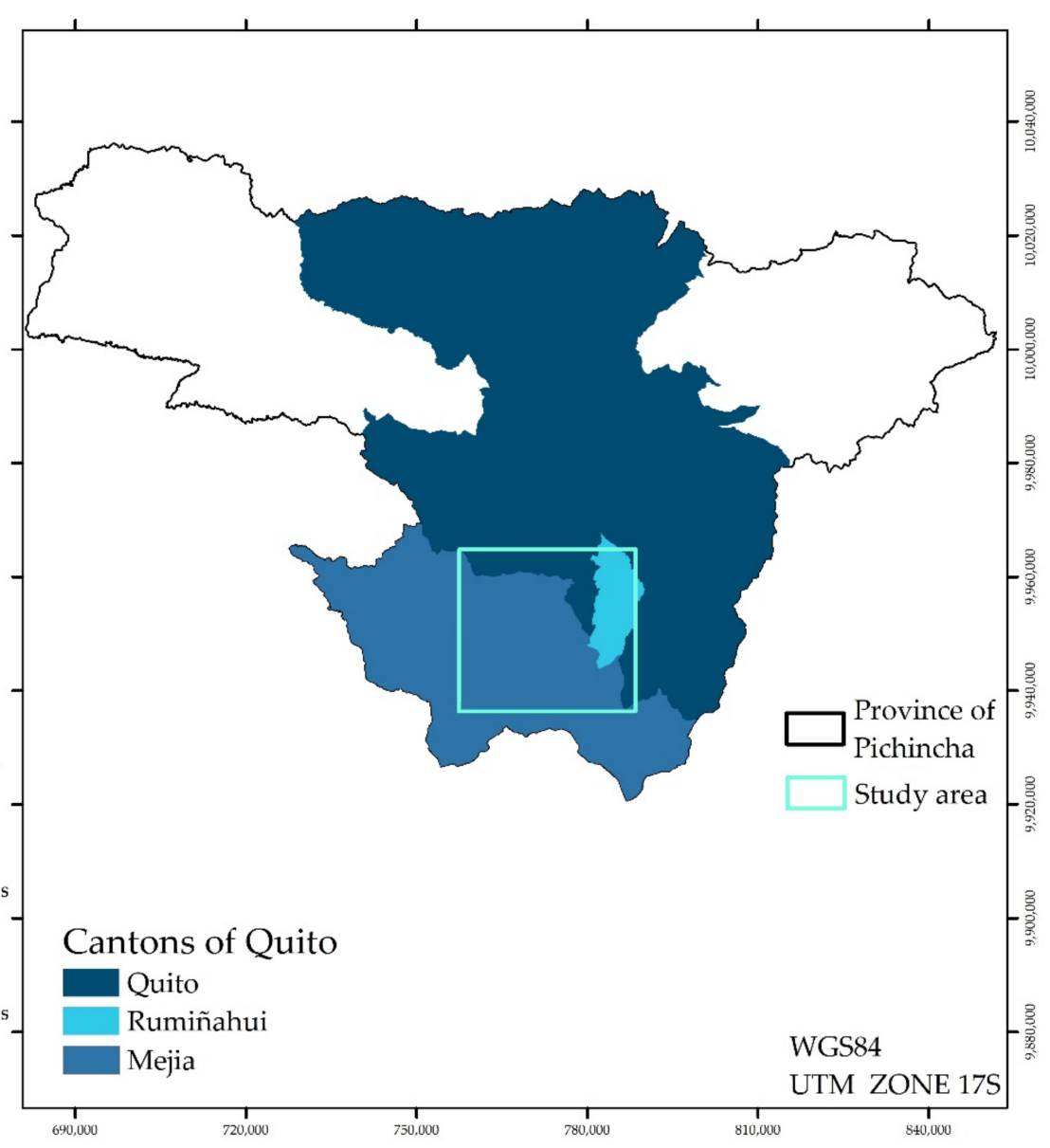

Figure 1. Location of the study area in the province of Pichincha, Ecuador. 


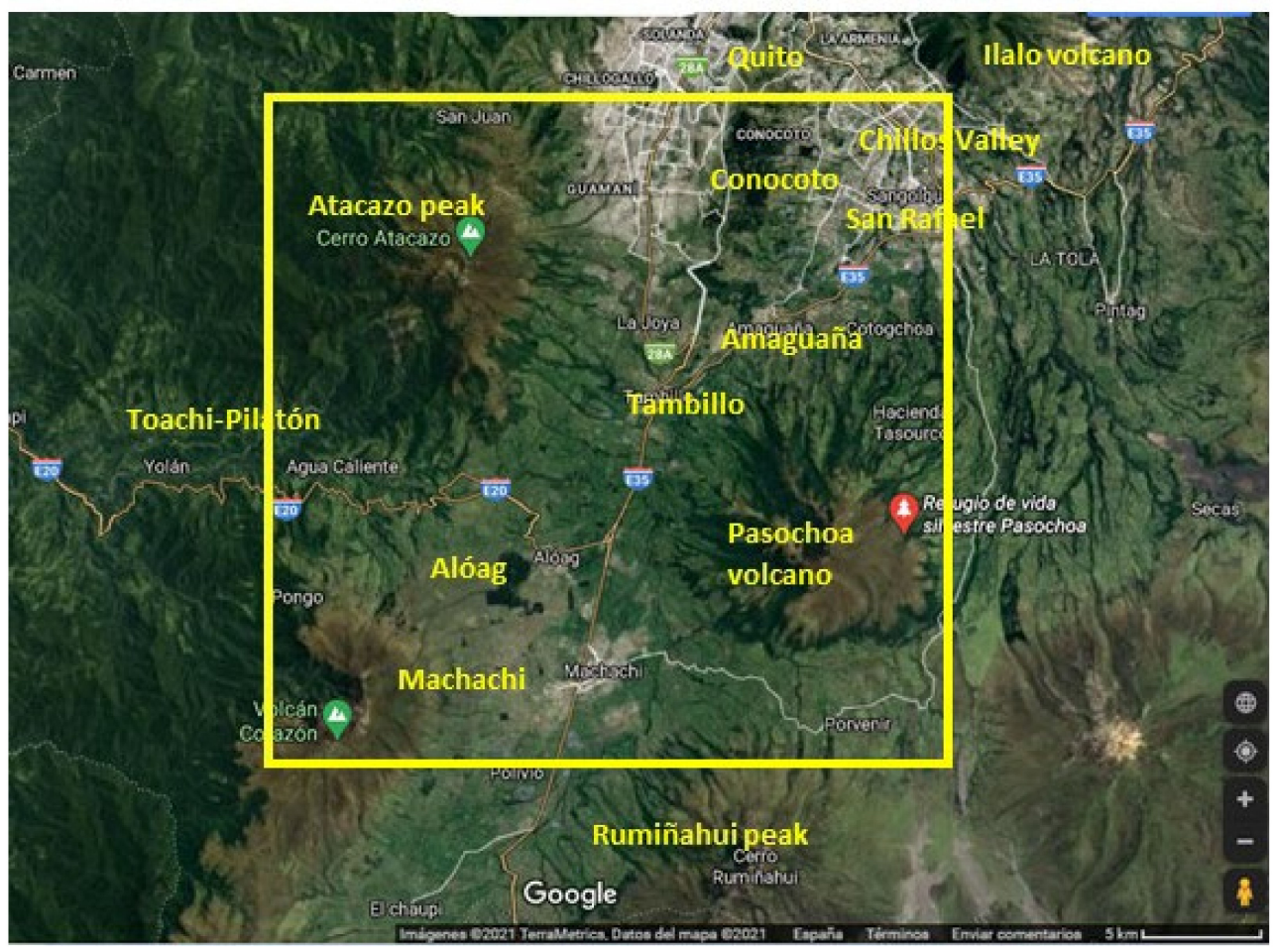

Figure 2. Study area. Google maps: https://www.google.es/maps/search/refugio+silvestre+ pasochoa+ecuador/@-0.4256733-78.697079,42181m/data=!3m1!1e3 (accessed on 16 February 2021).

The climate in this region is typical of Andean areas with average temperatures of $14{ }^{\circ} \mathrm{C}$, located over $2945 \mathrm{~m}$ above sea level. The orientation and geographic position of the valley cause the climate to change from humid tropical to high Andean.

This is an important climatic zone with high biodiversity in the natural areas where endemic and vulnerable species of fauna and flora coexist in Andean ecosystems [51,52].

Table 1 shows the 2018 land use distribution in the study area and its description [53], which were developed by the Ministry of the Environment and Water of Ecuador.

Table 1. Land use types in the study area.

\begin{tabular}{|c|c|c|c|}
\hline Land Use [53] & Definition & Area $\left(\mathrm{km}^{2}\right)$ & Percent \\
\hline Forest plantation & Anthropically established tree stand with one or more forest species. & 23.64 & $2.68 \%$ \\
\hline $\begin{array}{l}\text { Areas with no } \\
\text { vegetation cover }\end{array}$ & $\begin{array}{c}\text { Areas generally devoid of vegetation which are not used for agriculture } \\
\text { or forestry due to their soil, climatic, topographic, or anthropic } \\
\text { limitations, although they may have other uses. }\end{array}$ & 3.88 & $0.44 \%$ \\
\hline Shrub vegetation & $\begin{array}{l}\text { Areas with a substantial component of non-tree native woody species. } \\
\text { They include degraded areas in transition to dense canopy coverage. }\end{array}$ & 66.13 & $7.50 \%$ \\
\hline Moorland & $\begin{array}{l}\text { High Andean vegetation is characterized by dominant non-arboreal } \\
\text { species that include fragments of native forest typical of the area. }\end{array}$ & 172.36 & $19.55 \%$ \\
\hline $\begin{array}{l}\text { Agriculture and } \\
\text { livestock }\end{array}$ & Agricultural areas and planted pastures. & 401.8 & $45.57 \%$ \\
\hline Native forest & $\begin{array}{l}\text { Primary or secondary arboreal ecosystem regenerated by natural } \\
\text { succession, characterized by the presence of trees of different native } \\
\text { species in an irregular structure with one or more strata. }\end{array}$ & 108.99 & $12.36 \%$ \\
\hline Infrastructure & Road and transport networks, industry, and social infrastructure. & 2.15 & $0.24 \%$ \\
\hline Natural water bodies & Surface static or moving water. & 0.62 & $0.07 \%$ \\
\hline Herbaceous vegetation & $\begin{array}{c}\text { Areas of spontaneously growing native herbaceous species receiving no } \\
\text { special care and used for sporadic grazing, wildlife, or } \\
\text { protection purposes. }\end{array}$ & 0.7 & $0.08 \%$ \\
\hline Urban area & Areas mainly occupied by homes and public buildings. & 101.34 & $11.51 \%$ \\
\hline
\end{tabular}


Agricultural land use occupies nearly $50 \%$ of the area. The development of agriculture has been favored by soils formed by marine volcano-sedimentary andesite rocks with a basalt composition, several rivers flowing through this area from the natural springs originating in the snowy mountains and the climate characteristics.

Pichincha province has 187,912 ha of agricultural land, of which 46,947 ha are permanent crops and the rest are transitory (potato and soft corn). Further, 195,901 ha are cultivated grasslands and 109,676 ha are natural pastures. Cattle is the main livestock, accounting for $6.63 \%$ of the national production [54]. Permanent crops in the Andes are mostly cultivated at lower elevations because of climate requirements and comprise mainly fruit trees associated with relatively well-endowed areas with less poverty, fertile soils and close to urban centers. They are correlated with a relatively high percentage of the rural population working in agriculture. As expected, natural vegetation is more dominant in economically poor areas, on poor soils and further away from roads and cities.

The Quito municipality, with 2,800,000 people [55], is the central node of the country and has a major influence over the Machachi Valley, where most of the administrative units are structured by rural zones which integrate the natural environment with the urban, industrial and social-economic reality [56]. In addition, these cantons are connected by the Pan American highway that allows the strengthening of relations between them.

\section{Methodology}

The methodology of this study comprises four stages (see Figure 3). The first covers the data preparation and processing in the ESRI ${ }^{\circledR}$ GIS software. These data consist of 2000 and 2018 land use maps and 15 predictive factors that affect land use change. In the second stage, the model is calibrated based on transition matrices, the weight of evidence methodology and the correlation calculation between predictive factors. In the third stage, the 2018 land uses are simulated, and the model is validated by means of cellular automata (CA) and reciprocal similarity analysis. Finally, in the last stage, the projections of future land use maps are generated using CA complementary techniques. The second, third and fourth stages were processed in the Dinamica Ego ${ }^{\circledR}$ software.

\subsection{Stage 1: Data Preparation}

The data required to develop the model include historical and recent land use maps and predictive factors that explain the changes in land use.

Two land use maps from 2000 and 2018 were processed in the model as dependent variables (see Figure 4). They were compiled by the Ministry of the Environment and Water of Ecuador (MAE), in a vector format and at a scale of 1:100,000 [53] and represent the territorial distribution of ten types of land uses in the study area: Forest plantation, areas with no vegetation cover, shrub vegetation, moorland, agriculture and livestock, native forest, infrastructure, natural water bodies, herbaceous vegetation and populated urban areas.

In this period, urban land use increased sharply. For instance, in the study area, it almost tripled in Quito along with Alóag in the south (see Figure 1), and there is also a marked reduction in native forest due to the increase in scrub and plantation covers.

The 2000 land use map was obtained from Landsat 7 and Aster images [57]. ASTER provides high-resolution images of planet Earth in 14 different bands of the electromagnetic spectrum, ranging from visible to thermal infrared light. The image resolution ranges from 15 to $90 \mathrm{~m}$ [57]. This land use map was validated with the Kappa index, which had a value of 0.7 [58]. The 2018 land use map was obtained from Landsat 8 images with a resolution of $30 \mathrm{~m}$, which were downloaded from the United States Geological Survey (USGS). The precision of the 2018 land cover map was evaluated by an independent consultant, maintaining the evaluation methodology proposed by Olofsson, 2013 [59], which has not yet been published [60]. 


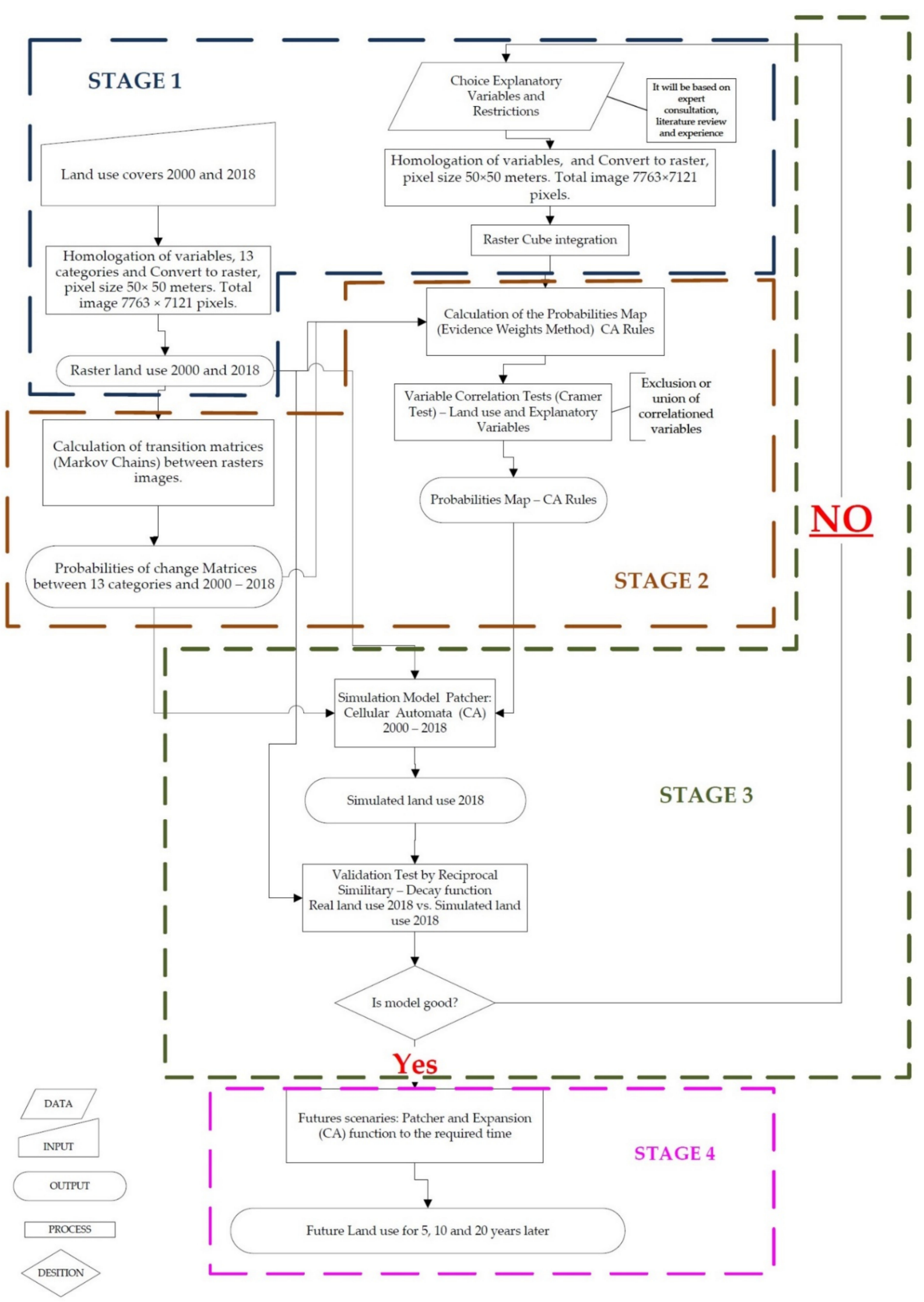

Figure 3. General model framework. 


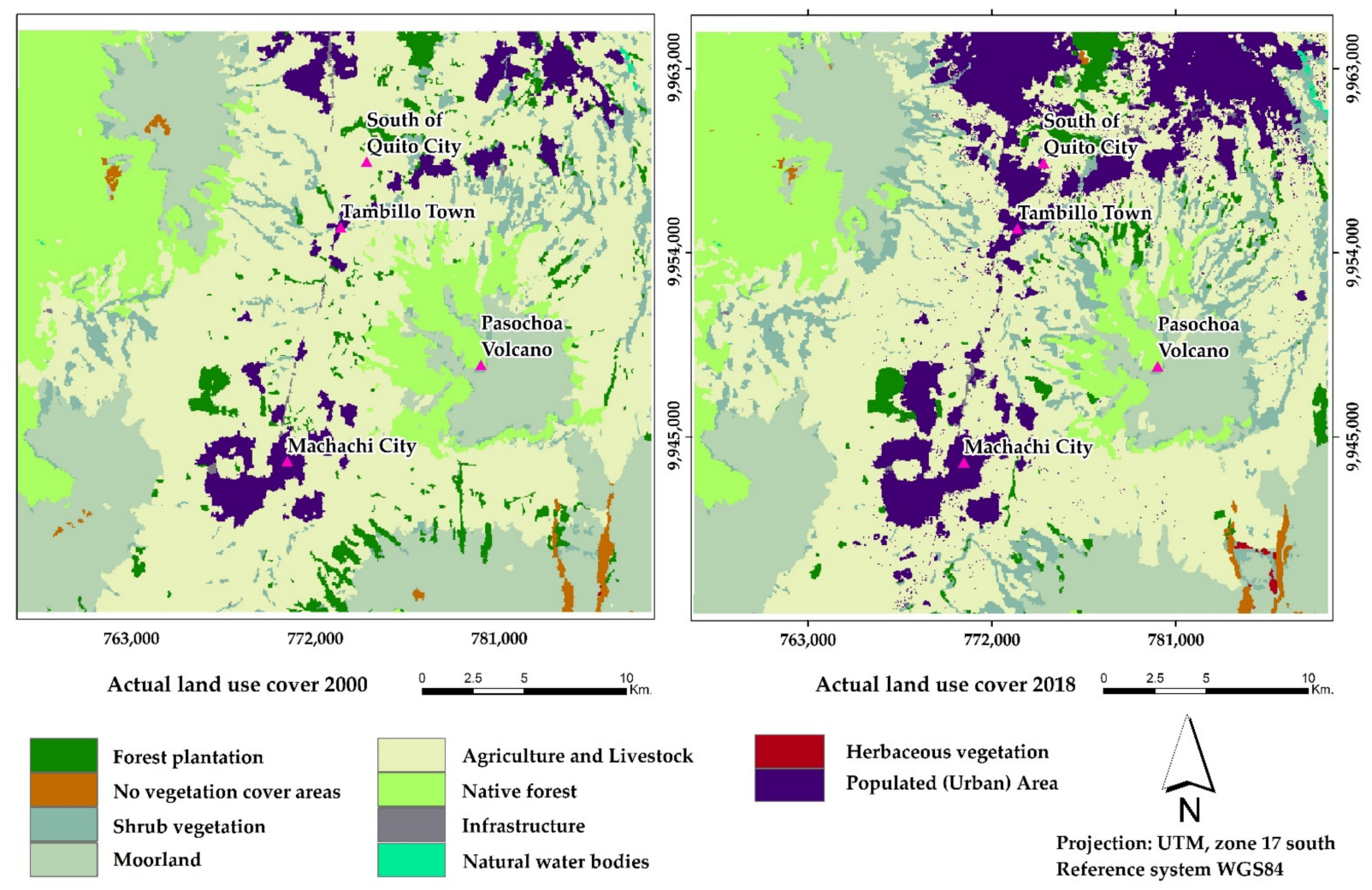

Figure 4. Land use maps from 2000 and 2018.

Regarding the independent variables or predictive factors, 15 variables that correspond to climate, social and physical components were considered to calibrate the model (see Table 2 and Figures 5-7). These maps were provided by the Military Geographic Institute of Ecuador (IGM) at a scale of 1:25,000 [61].

Table 2. Description of the predictive factors.

\begin{tabular}{|c|c|c|}
\hline Factor & Name of the Map & Data Sources and Construction Method of the Maps * \\
\hline Physical & Slope & Obtained from the altitude map [62]. \\
\hline Physical & $\begin{array}{l}\text { Euclidean distance to } \\
\text { roads }\end{array}$ & Obtained from the infrastructure and service map [63]. \\
\hline Physical & Potential land use & $\begin{array}{l}\text { Obtained from the slope, temperature, and precipitation maps, and from the following } \\
\text { soil maps: effective depth; surface texture, stoniness, fertility, salinity, toxicity, drainage, } \\
\text { flooding periods and soil moisture [62]. }\end{array}$ \\
\hline Physical & Landslide risk & $\begin{array}{l}\text { Obtained from the land use and land cover map, geomorphology map, seismic } \\
\text { movement data and precipitation map [64]. }\end{array}$ \\
\hline Social & $\begin{array}{l}\text { Access to services } \\
\text { (electricity, drinking } \\
\text { water and sewerage) }\end{array}$ & Obtained from the infrastructure and service map [63]. \\
\hline Social & Access to education & Obtained from the infrastructure and service map [63]. \\
\hline Social & Access to healthcare & Obtained from infrastructure and service map [63]. \\
\hline Social & Housing types & Obtained from the building material map [65]. \\
\hline Social & Foreign immigration & $\begin{array}{l}\text { Obtained from the data: total population; population density; population distribution; } \\
\text { migratory movements; internal and external migration [65]. }\end{array}$ \\
\hline Social & Internal immigration & $\begin{array}{l}\text { Obtained from the data: total population; population density; population distribution; } \\
\text { migratory movements; internal and external migration [65]. }\end{array}$ \\
\hline Social & Education level & Obtained from the data: coverage of education services, education level [65]. \\
\hline Social & Illiteracy & Obtained from the illiteracy rate [40]. \\
\hline Climate & Water deficit & Obtained from the maps: precipitation, temperature, dry months, and water deficit [62]. \\
\hline Climate & Evapotranspiration & Obtained from the maps: precipitation, temperature, water deficit and vegetation [62]. \\
\hline Climate & Rainfall & Obtained from the maps: precipitation [62]. \\
\hline
\end{tabular}



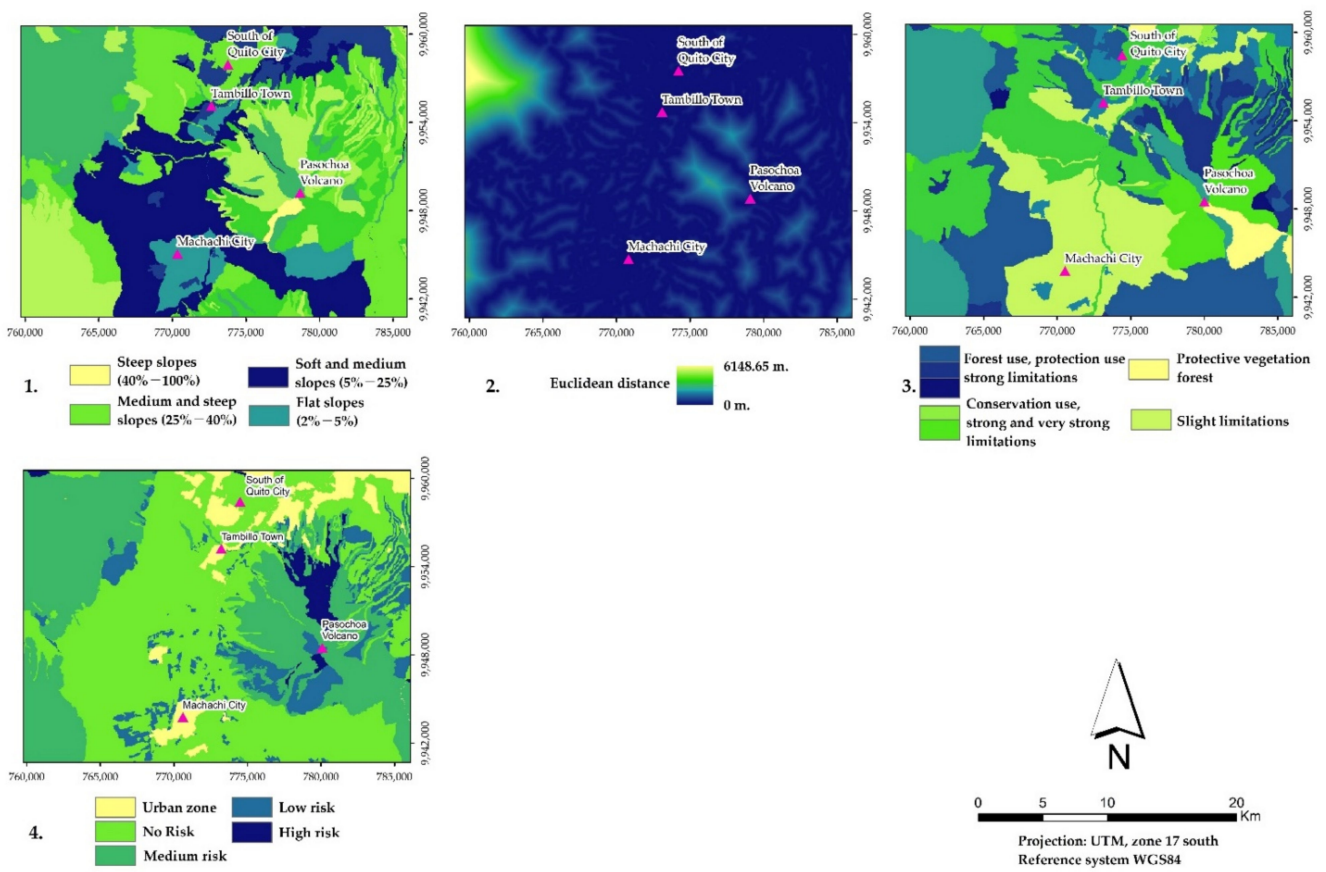

Figure 5. Predictive physical factors: (1) Slope; (2) Distance to roads; (3) Potential land use; (4) Landslide risk.

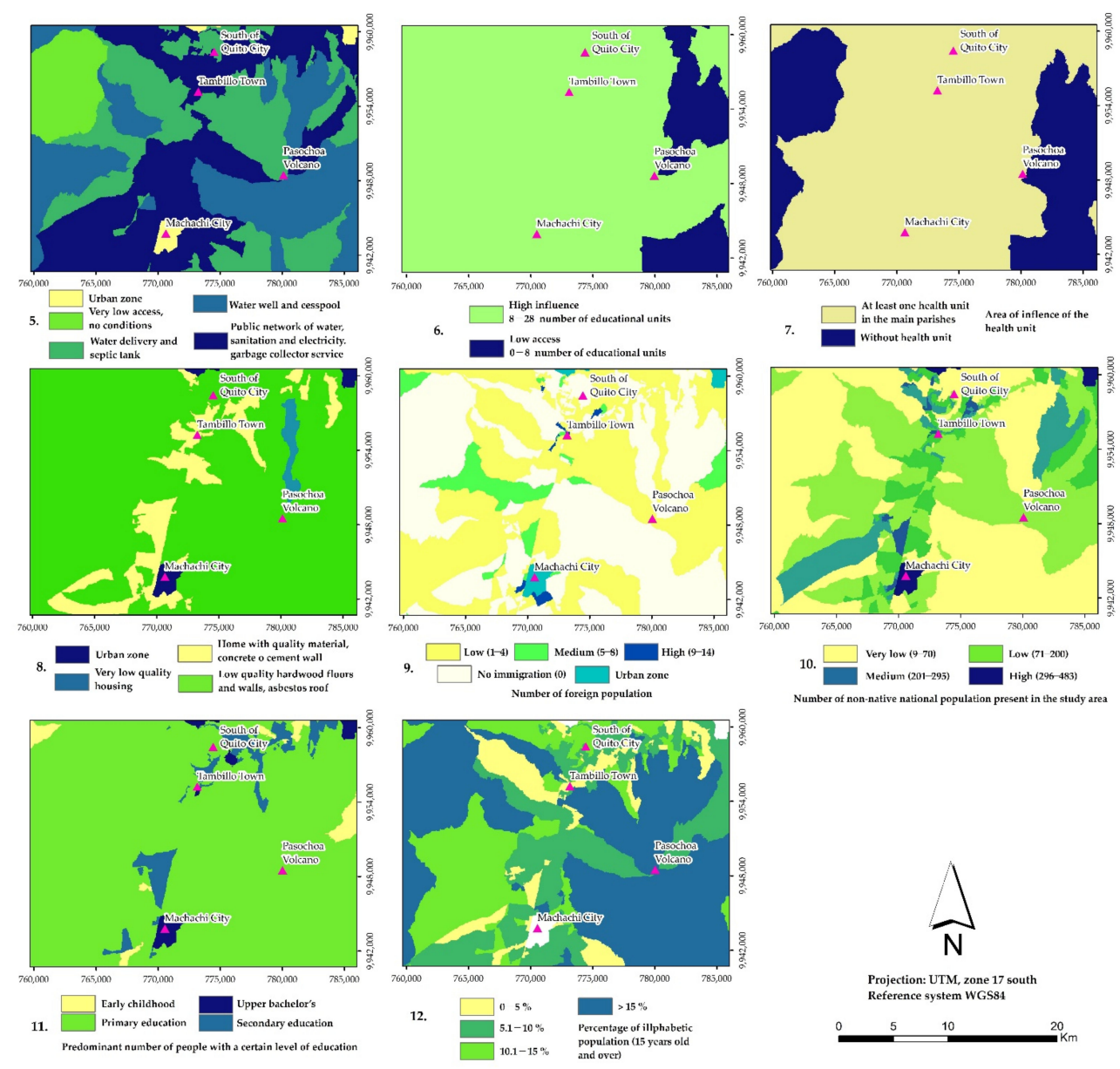

Figure 6. Predictive social factors: (5) Access to services; (6) Access to education; (7) Access to healthcare. (8) Housing types; (9) Foreign immigration; (10) Internal immigration; (11) Level of education; (12) Illiteracy. 

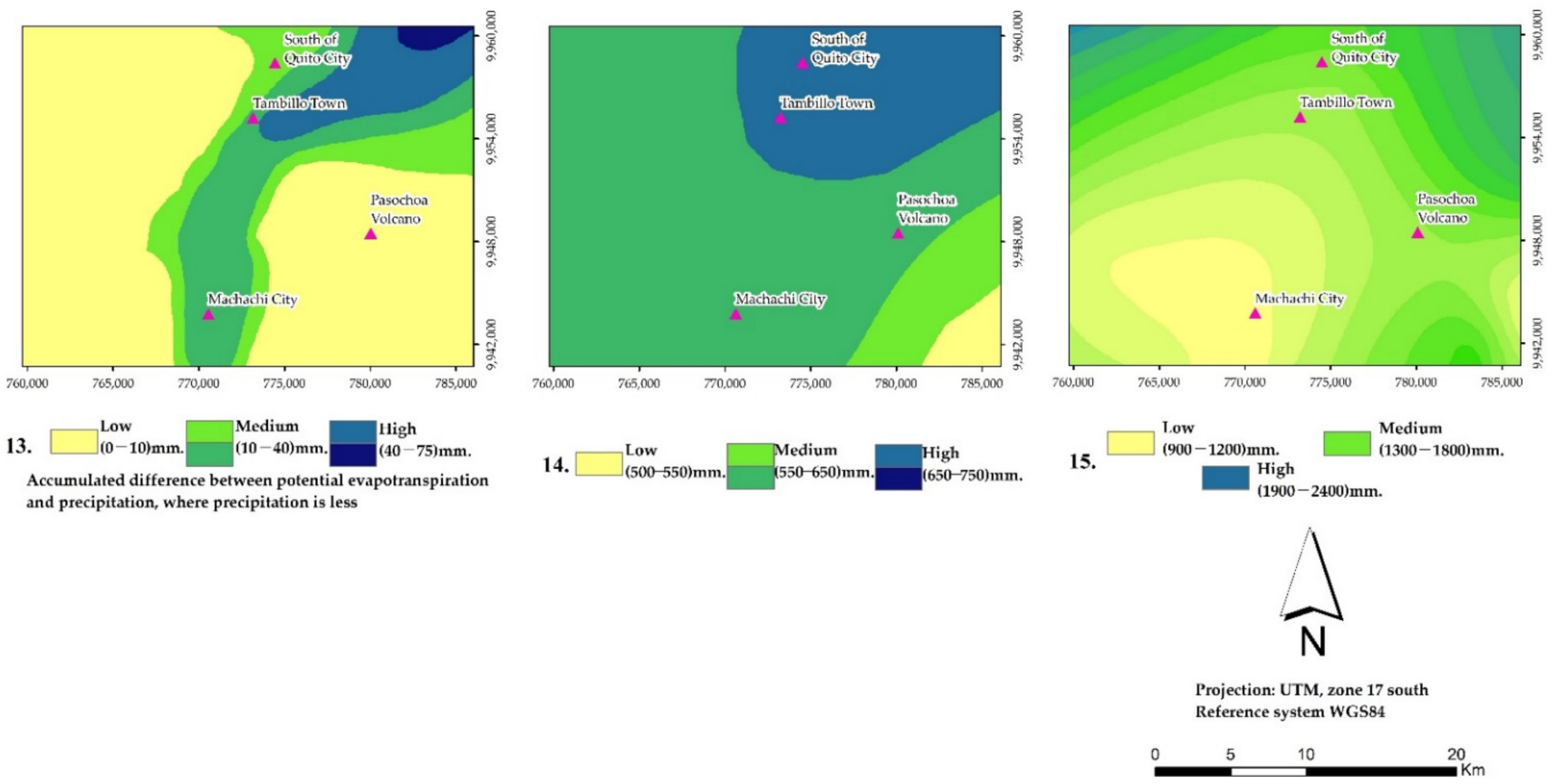

Figure 7. Predictive climate factors: (13) Water deficit; (14) Evapotranspiration; (15) Rainfall.

All these input maps were rasterized from a geodatabase in vector format published by the Project for the Generation of Geoinformation for Land Management at the national scale of 1:25,000 into $50 \times 50 \mathrm{~m}$ per pixel (for a total of $7763 \times 7121$ pixels). The pixel size was established considering the land use cover resolution $(1: 100,000)$, which allows a rasterization of up to $30 \mathrm{~m} \times 30 \mathrm{~m}$. However, based on direct observation and the calculation of the transition matrices for the change in the different categories, the resolution of $50 \mathrm{~m} \times 50 \mathrm{~m}$ provides a more accurate representation of the causes and rates of land use changes, especially in urban areas. In addition, since the different stages of the model demand only category maps, the quantitative variable "Distance to roads" was transformed into a qualitative variable by dividing its value into 4 intervals with a range of $1500 \mathrm{~m}$.

These 15 independent variables were structured in a multidimensional raster layer for efficient spatiotemporal analysis and visualization (raster cube) [42] as input for the next stage.

\subsection{Stage 2: Model Calibration}

"Calibration" in this work refers to the "estimation and adjustment of model parameters and constants to improve the agreement between model output and a data set" [66]. The cellular automata logic needs rules to change from a cell-specific land use to another under special conditions (see the structure of this stage in Figure 3). The information to define these CA rules comes from the probability maps built by combining the historical transition matrices with predictive factors.

The historical transition matrices were calculated by applying the probability of change by the land use transition Markov chains to reflect the percentage of land uses that changed between 2000 and $2018[67,68]$. The matrices express the changes produced in discrete periods of time of one year, in this case, changes occurring between land uses in 18 years.

The predictive variables were processed with the weight of evidence (WoE) method to compute the final maps according to the transition probabilities [69]. These maps show the 
areas where the changes are more likely to occur [70]. As WoE is based on the Bayesian method, the expressions of the probabilities are:

$$
\begin{gathered}
O\{A \mid B\}=\frac{P\{A \mid B\}}{P\{\bar{A} \mid B\}} \\
O \log \{A \mid B\}=\log \{A\}+W^{+}
\end{gathered}
$$

where $A$ represents the event or phenomenon (land uses) influenced by a factor or predictor $B$, and $W$ is the weight of the evidence of occurrence of event $A$, given a spatial factor $B$.

For several predictive factors this is expressed as follows:

$$
P\{\text { change } \mid M \cap V \cap S \ldots N\}=\frac{e^{\sum W_{N}}}{1+e^{\sum W_{N}}}
$$

One of the main indicators in the calibration process is the correlation of variables. The predictive factors should be spatially independent, and this point was tested using Cramer's $V$ coefficient, which was performed for each pair of explanatory categorical variables:

$$
V=\sqrt{\frac{\chi^{2}}{n(\min [r, c]-1)}}
$$

where $\chi^{2}$ is the chi-square test of independence statistic; $n$ is the sample size, $r$ is the number of rows in the contingency table, and $c$ the number of columns.

If the value of the coefficient $V$ is greater than 0.6 , there is a strong association between the variables $[71,72]$, and one of the factors would be eliminated or combined with others [70].

\subsection{Stage 3: Simulation of Land Use Change Maps and Validation}

Finally, the 2018 simulated land use map was generated (see the description of this stage in Figure 3) and compared to the real cover to validate the prediction level [73,74].

The validation process was carried out to verify the level of prediction of the simulation generated by the constructed spatial model [66]. The data used in this step were the 2018 real land use map and the 2018 simulated land use map, as seen in Figure 3.

To estimate the reliability of the model, the validation process compared the real land use cover in 2018 with the simulated land use cover for the same year, based on (1) neighborhood windows and (2) on the confusion matrix. The first process applies an exponential decay function to determine the probability of similarity of the cells for a specific window (kernel) related to the central cell. In the evaluation, multiple window sizes were applied since it is not very likely that the simulated and real maps will match cell by cell, although these maps may have similar spatial patterns for a specific neighborhood of the cells [75]. The exponential decay function that calculates the probability of similarity is expressed by Equation (5).

$$
y=\frac{1}{2^{\left(\frac{d}{A}\right)}}
$$

where $d$ is the distance from the center of the window and $A$ is the attenuation factor that controls the speed of the decrease of the function values inside the kernel [76].

In this work, the attenuation factor $A$ was 10 (see Figure 8), as land use patterns can appear as far as $3000 \mathrm{~m}$ from each central cell [77]. 


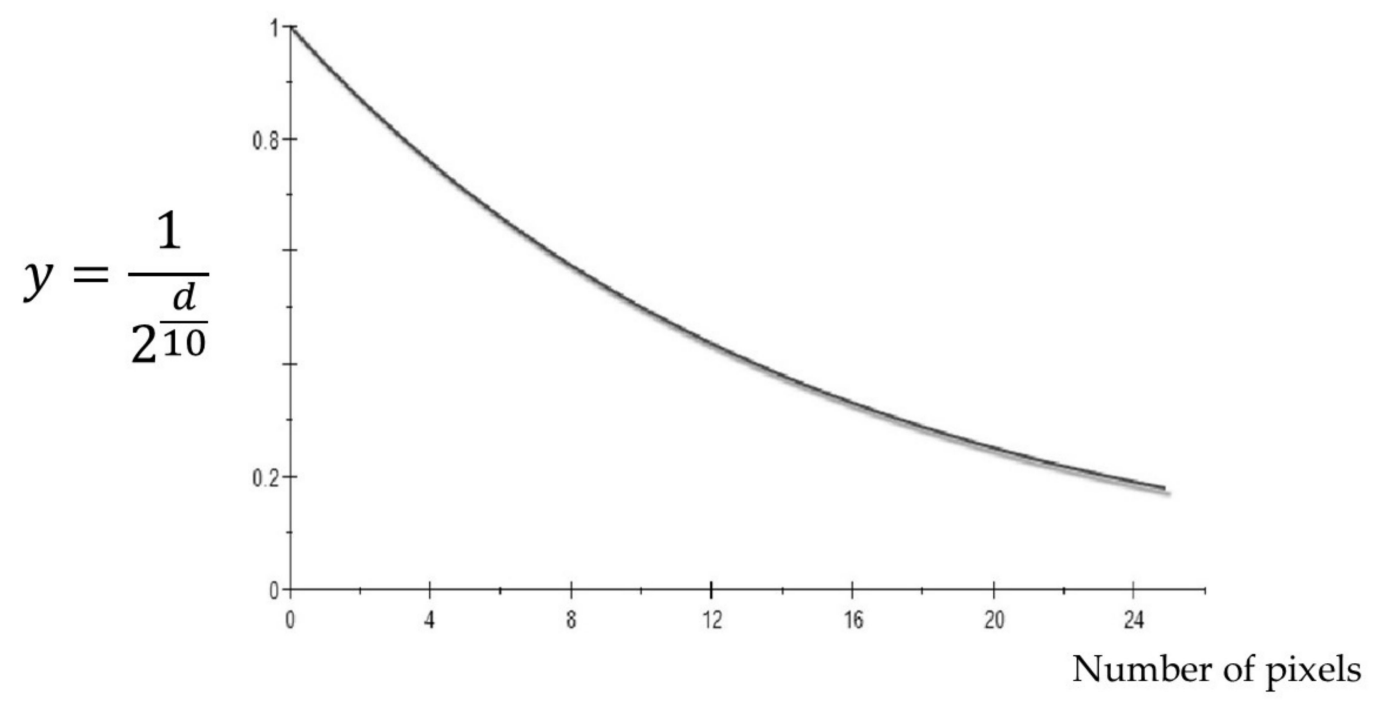

Figure 8. Decay function for an attenuation factor of 10 .

The confusion matrix provides the kappa variations measures of the agreement used in this work: Kno, Kstandard and Klocation [78-80]. The Kstandard index is a measure of the simulated map's ability to attain perfect classification, the Klocation index expresses the locational accuracy of pixels in the simulation, and the Kno index describes the proportion of correctly classified pixels relative to the expected proportion correctly classified without regard to location error [78].

\subsection{Stage 4: Future Scenarios}

Future scenarios for 2023, 2028 and 2038 were built using the same methodology: Transition matrices, a raster cube of predictor factors, the weight of the evidence coefficient based on the transition of land uses from the year 2000 to 2018, predictive factors and actual 2018 land use, which generates new patches of land uses through a seeding mechanism.

\section{Results}

The results show the ability of the cellular automata DinamicaEgo ${ }^{\circledR}$ software to produce accurate simulations using the available data; the simulated scenarios show the feasible evolution of land uses and the social and environmental challenges that could arise.

\subsection{Validation}

In the model calibration stage, the results of Cramer's V coefficient-less than 0.6 for all cases-indicated that the correlations between all independent factors were not strong [71].

Table 3 shows the accuracy of the validation process. It can be seen how the increase in similarity values decreases sharply from 25 pixels, at $1250 \mathrm{~m}$. This result agrees with Figure 8 of the decay function for an attenuation factor of 10, in which the slope of the curve smooths sharply after 20 pixels, i.e., the increase in similarity is very small. For the allocation of land uses, the model was validated spatially with $72 \%$ similarity for a $7 \times 7$-pixel window $[81,82]$ indicate that a similarity value higher than $50 \%$ between the compared maps is satisfactory for model validation. 
Table 3. Similarity values of the simulations.

\begin{tabular}{ccc}
\hline $\begin{array}{c}\text { Window Size } \\
\text { (Num. of Pixels) }\end{array}$ & Similarity (\%) & $\begin{array}{c}\text { Real Evaluation Distance on } \\
\text { the Map (Pixel Size 50 m) }\end{array}$ \\
\hline 1 & $41.5 \%$ & $50 \mathrm{~m}$ \\
7 & $71.9 \%$ & $350 \mathrm{~m}$ \\
13 & $77.0 \%$ & $650 \mathrm{~m}$ \\
19 & $79.8 \%$ & $950 \mathrm{~m}$ \\
25 & $81.3 \%$ & $1250 \mathrm{~m}$ \\
31 & $82.0 \%$ & $1550 \mathrm{~m}$ \\
37 & $82.4 \%$ & $1850 \mathrm{~m}$ \\
43 & $82.7 \%$ & $2150 \mathrm{~m}$ \\
49 & $82.8 \%$ & $2450 \mathrm{~m}$ \\
55 & $82.9 \%$ & $2750 \mathrm{~m}$ \\
61 & $83.0 \%$ & $3050 \mathrm{~m}$ \\
67 & $83.0 \%$ & $3350 \mathrm{~m}$ \\
\hline
\end{tabular}

Regarding the kappa measures, the results showed that the value of the Kstandard was 0.72. In evaluating the overall accuracy, using the value of Kno is better than the Kstandard [80]. Kno was 0.77 , and the Klocation value of 0.72 indicated that the model provided a logical representation of the location.

Figure 9 shows the initial 2000 land use map, the simulated 2018 land use map and the real 2018 land use map. For the quantitative validation, the differences between the real map and simulated map are given in Table 4.

Table 4 shows the transition percentages between land uses in 2000 and 2018. The types of land use and land covers were different in 2000 and 2018, as uses 11 (Pastureland), 12 (Agricultural mosaic) and 13 (Annual crop) in 2000 were grouped in use 5 (Agriculture and Livestock) in 2018. This reclassification explains the high percentages in the transition of uses 11,12 and 13 to use 5 . The table also shows the increase in urban land use area and the transformation of native forest into shrub cover. Figure 10 shows the land cover transition map associated to this table.

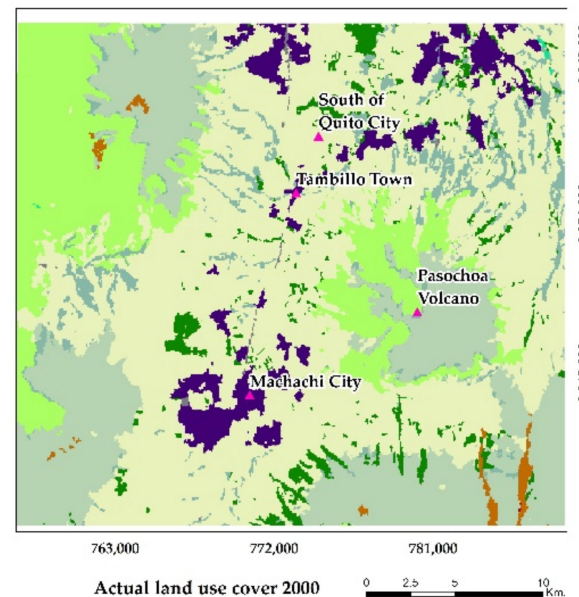

Actual land use cover 2000

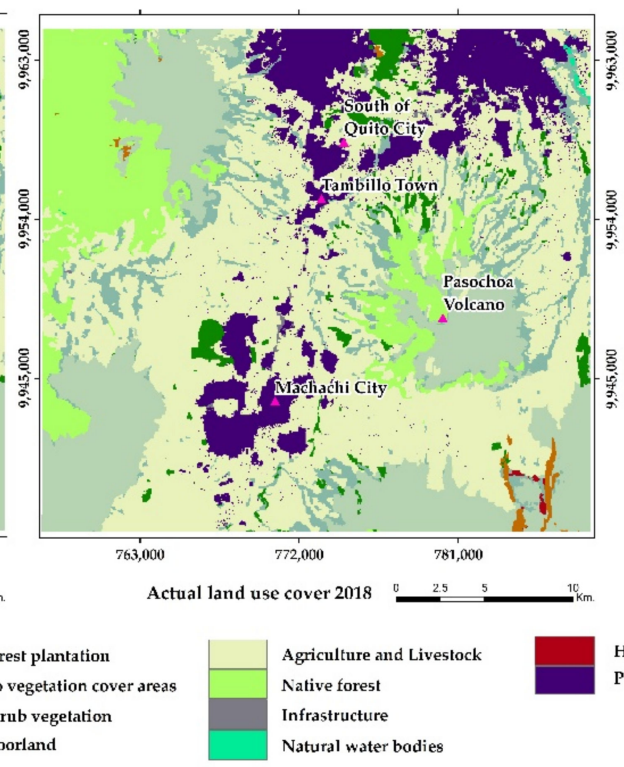

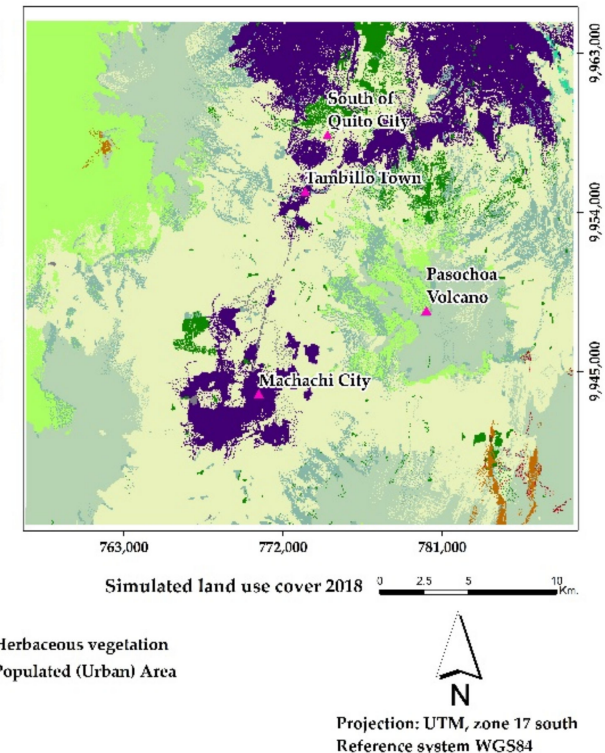

Figure 9. From left to right: Real land use map in 2000, real land use map in 2018 and simulated land use map for 2018. 
Table 4. Transition matrix between 2000 and actual land use maps.

\begin{tabular}{|c|c|c|c|c|c|c|c|c|c|c|c|}
\hline & & \multicolumn{10}{|c|}{ Actual Land Use 2018} \\
\hline & & 1 & 2 & 3 & 4 & 5 & 6 & 7 & 8 & 9 & 10 \\
\hline \multirow{12}{*}{$\begin{array}{c}\text { Actual } \\
\text { land } \\
\text { use } \\
2000\end{array}$} & 1 & & $0.0178 \%$ & $1.4132 \%$ & $0.2787 \%$ & $1.7 \%$ & $0.0053 \%$ & $0.0135 \%$ & $0.0014 \%$ & $0.0245 \%$ & $0.3267 \%$ \\
\hline & 2 & $0.0235 \%$ & & $0.1850 \%$ & $2.1732 \%$ & $0.1 \%$ & $0.0104 \%$ & & & $0.0573 \%$ & \\
\hline & 3 & $0.3819 \%$ & $0.0033 \%$ & & $0.2689 \%$ & $1.7 \%$ & $0.0199 \%$ & $0.0103 \%$ & $0.0223 \%$ & $0.0120 \%$ & $0.2676 \%$ \\
\hline & 4 & $0.0248 \%$ & $0.0134 \%$ & $0.0979 \%$ & & $0.6 \%$ & $0.0078 \%$ & & & $0.0126 \%$ & $0.0002 \%$ \\
\hline & 6 & $0.0297 \%$ & $0.0046 \%$ & $0.5058 \%$ & $0.0325 \%$ & $0.6 \%$ & & & & & $0.0007 \%$ \\
\hline & 7 & & & & & $0.2 \%$ & & & & & $3.1065 \%$ \\
\hline & 8 & & & $0.1646 \%$ & & $0.0 \%$ & & & & & $0.2469 \%$ \\
\hline & 9 & & $0.3968 \%$ & & $4.3651 \%$ & & & & & & \\
\hline & 10 & & & $0.0017 \%$ & & $0.0 \%$ & & $0.0003 \%$ & $0.0003 \%$ & & \\
\hline & 11 & $0.1176 \%$ & & $0.2227 \%$ & $0.0258 \%$ & $4.5 \%$ & $0.0024 \%$ & $0.0206 \%$ & & & $0.6819 \%$ \\
\hline & 12 & $0.1820 \%$ & $0.0105 \%$ & $0.4734 \%$ & $0.0260 \%$ & $3.8 \%$ & $0.0243 \%$ & $0.0170 \%$ & $0.0063 \%$ & $0.0002 \%$ & $0.9976 \%$ \\
\hline & 13 & $0.0770 \%$ & $0.0105 \%$ & $0.0832 \%$ & $0.0215 \%$ & $5.2 \%$ & $0.0014 \%$ & $0.0180 \%$ & & & $0.1689 \%$ \\
\hline
\end{tabular}

Note. Read only from left to right. 1-Forest plantation; 2-No vegetation cover; 3-Shrub vegetation; 4-Moorland; 5-Agriculture and Livestock; 6-Native forest; 7-Infrastructure; 8-Natural water bodies; 9-Herbaceous vegetation; 10—Populated (Urban) area; 11-Pastureland; 12-Agricultural mosaic; 13-Annual crop.

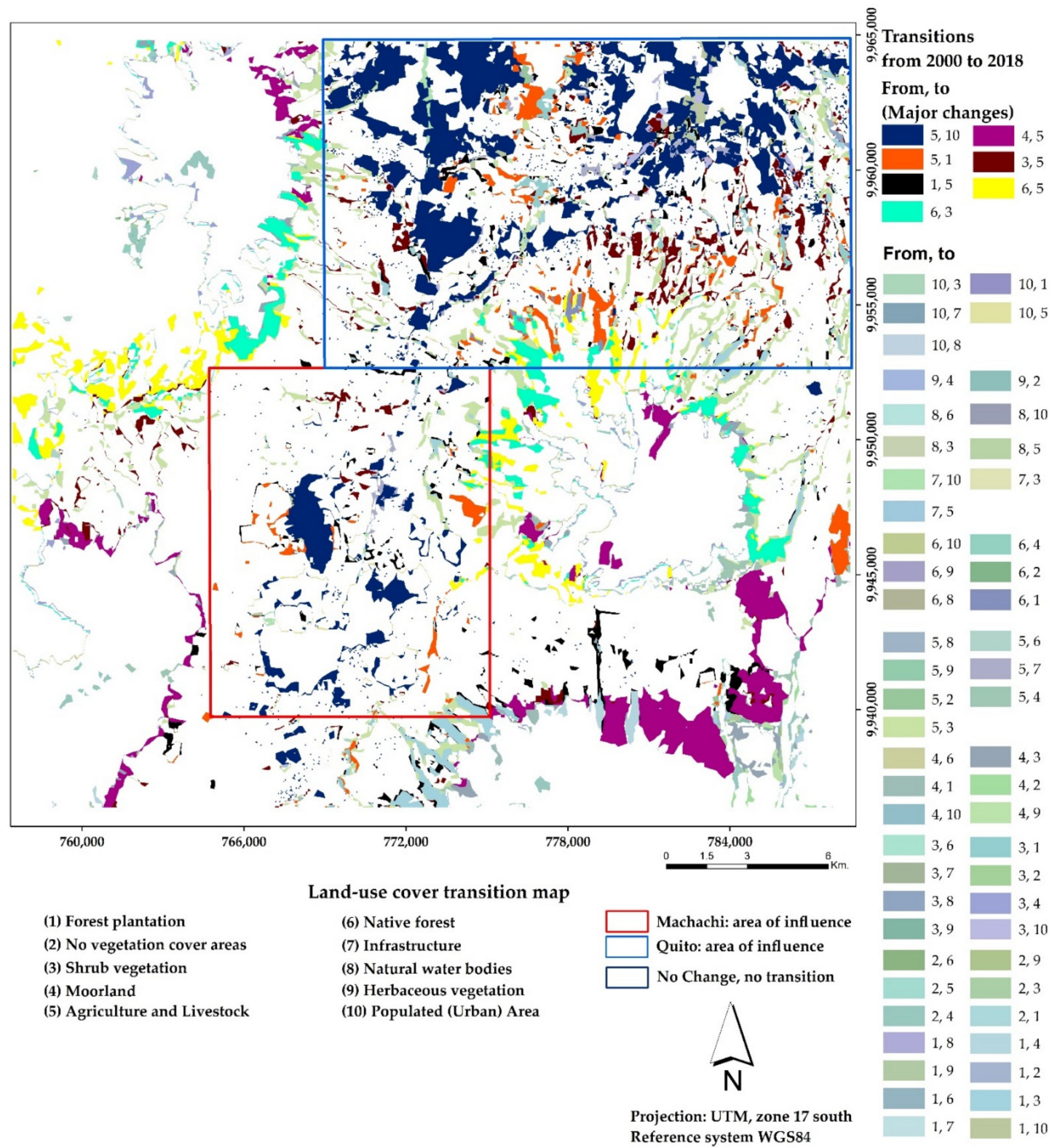

Figure 10. Land use transition map from 2000 land use map to 2018 land use map. 
The difference between the real and the simulated map in the validation step (see Table 5) shows that the model slightly underestimated the land uses for forest plantation, shrub vegetation, moorland, agriculture and livestock, native forest and infrastructure in $0.04 \%$ to $0.13 \%$ of cells (see Figure 11 ). It also slightly overestimated the land uses for herbaceous and urban area in $0.09 \%$ and $0.45 \%$ of cells, respectively (see Figure 12). These differences are acceptable according to [83]. The results therefore demonstrate the accuracy of the model and its applicability.

Table 5. Area differences between the real and simulated 2018 land use maps.

\begin{tabular}{ccccc}
\hline \multirow{2}{*}{ Land Use Name } & \multicolumn{2}{c}{ Actual Land Use 2018 } & \multicolumn{2}{c}{ Simulated Land Use 2018 } \\
& Area/km & Area/\% & Area/km $\mathbf{k n}^{\mathbf{2}}$ & Area/\% \\
\hline Forest plantation & 23.64 & $2.68 \%$ & 23.31 & $2.64 \%$ \\
Areas with no vegetation cover & 3.88 & $0.44 \%$ & 3.93 & $0.44 \%$ \\
Shrub vegetation & 66.13 & $7.50 \%$ & 64.78 & $7.37 \%$ \\
Moorland & 172.36 & $19.55 \%$ & 171.53 & $19.45 \%$ \\
Agriculture and livestock & 401.8 & $45.57 \%$ & 401.09 & $45.50 \%$ \\
Native forest & 108.99 & $12.36 \%$ & 107.91 & $12.24 \%$ \\
Infrastructure & 2.15 & $0.24 \%$ & 2.04 & $0.23 \%$ \\
Natural water bodies & 0.62 & $0.07 \%$ & 0.71 & $0.08 \%$ \\
Herbaceous vegetation & 0.7 & $0.08 \%$ & 0.83 & $0.09 \%$ \\
Urban area & 101.34 & $11.51 \%$ & 105.48 & $11.96 \%$ \\
\hline Total $/ \mathrm{km}^{2}$ & \multicolumn{3}{c}{881.61} \\
\hline
\end{tabular}

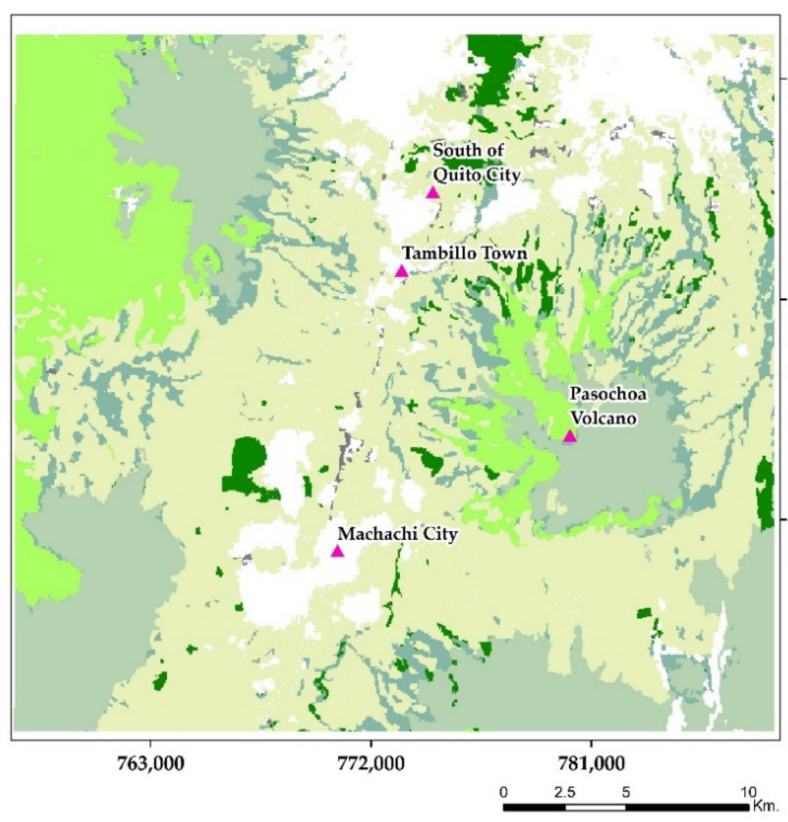

Actual land use cover 2018

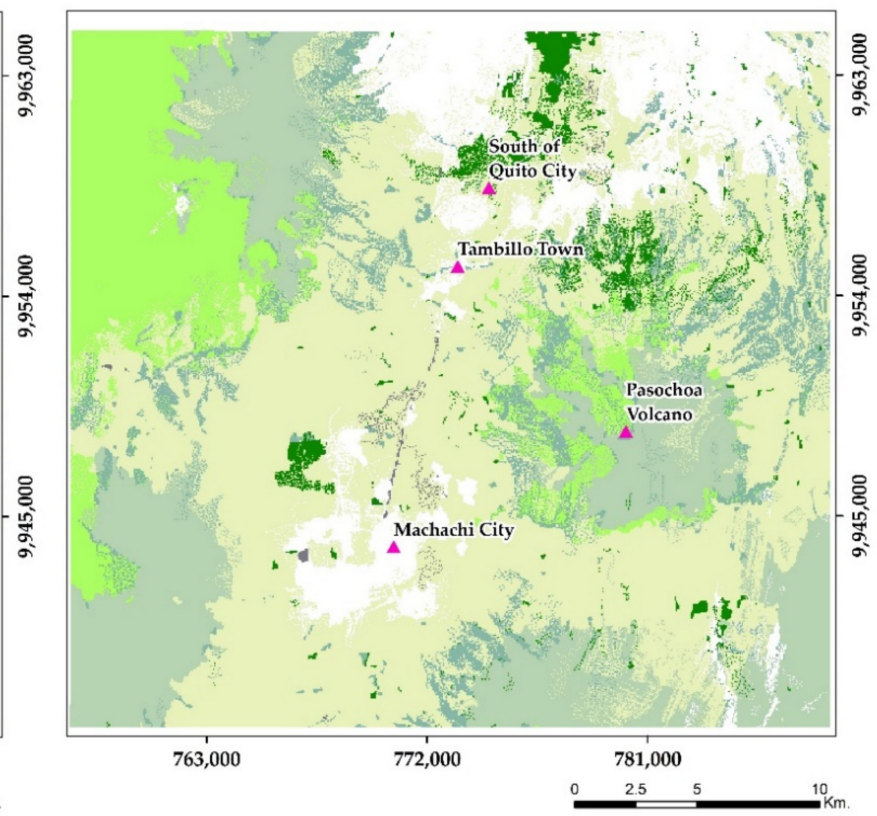

Simulated land use cover 2018

Underestimated zones by model
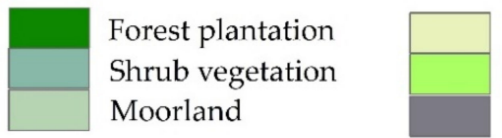

Agriculture and Livestock Native forest

Infrastructure

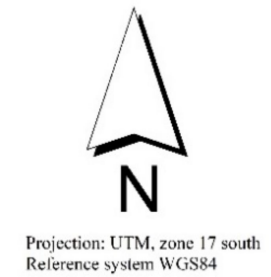

Figure 11. Underestimated areas by the model for Forest plantation, Shrub vegetation, Moorland, Agriculture and Livestock and Infrastructure land uses. 


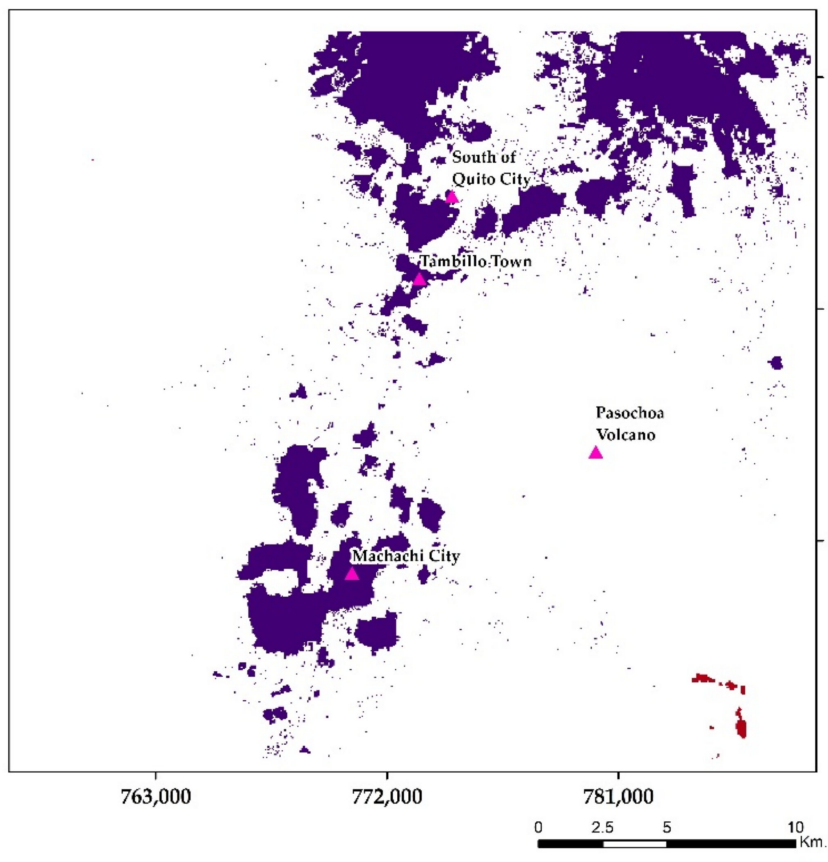

Actual land use cover 2018

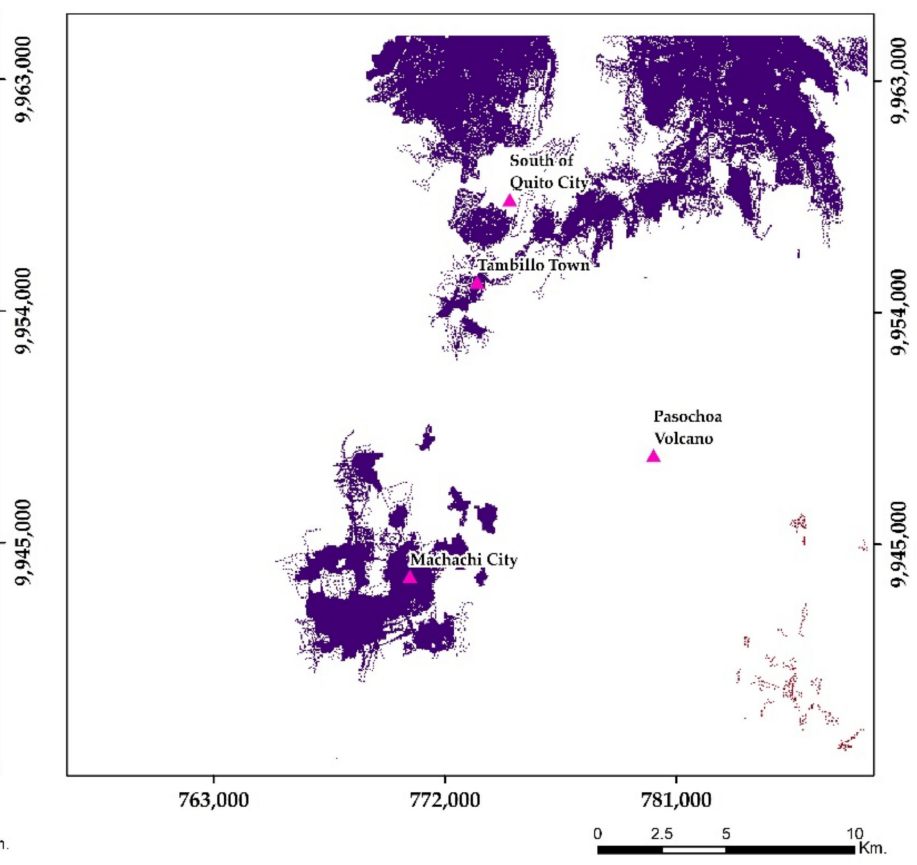

Simulated land use cover 2018

\section{Overestimated zones by model}

Herbaceous vegetation

Populated (Urban) Area

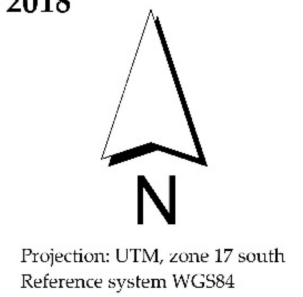

Figure 12. Overestimated areas by the model for Urban and Herbaceous vegetation land uses.

\subsection{Simulated Scenarios}

Three future scenarios were simulated from the 2018 land use map using DinamicaEGO software, corresponding to the 2023 and 2028 and 2038 land use maps.

We analyzed the changes in the whole study area and in the area to the south of Quito since the highest growth in Quito is in this direction [84]; and in the rural areas of Machachi and Alóag due to the pressure of the development of Quito on natural and rural areas. Figure 13 shows these future forecasting scenarios. Table 6 presents the predicted area of each land use in the different scenarios and the net variation from the initial situation in 2018. In Quito's area of influence, there are no land uses corresponding to high altitudes such as moorland or areas of herbaceous vegetation. The area of Machachi and Alóag is at the bottom of the Machachi Valley and on the lower slopes of the Pasochoa volcano and the Andes. There is no representation of areas of vegetation cover such as moorland, natural water bodies and herbaceous vegetation land uses (see Table 6).

The analysis of the balance of the changes in land uses throughout the study area shows that urban land use will undergo the greatest net increase. The top left of Figure 14 shows how the variation in this land use in the whole study area and in the Quito area follows the same trend, so the Quito area will absorb this growth. On the other hand, there will be very little variation in this land use in the Machachi area. Growth in Quito is predicted to be $6 \mathrm{~km}^{2}$ in 2023, $7 \mathrm{~km}^{2}$ in 2028 and up to $13 \mathrm{~km}^{2}$ in 2038, representing an increase in its area of as much as 35\% between 2018 and 2038. 


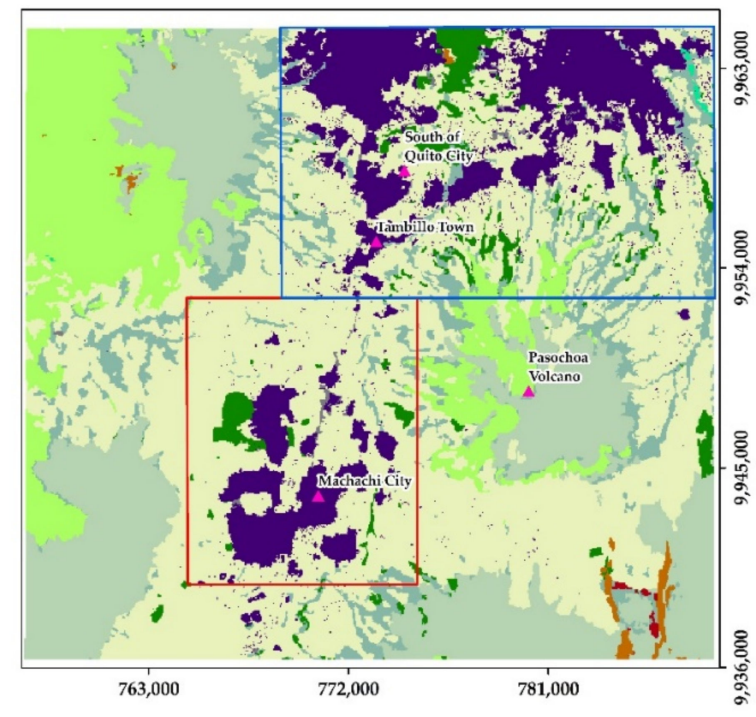

Actual land use cover 2018
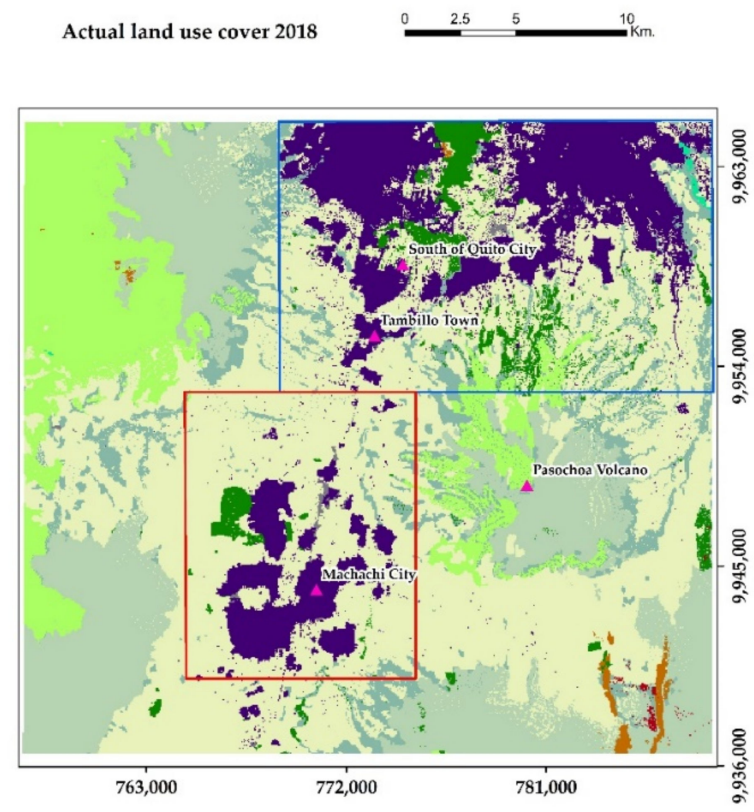

Simulated land use 10 years later

Forest plantation No vegetation cover areas Shrub vegetation Moorland

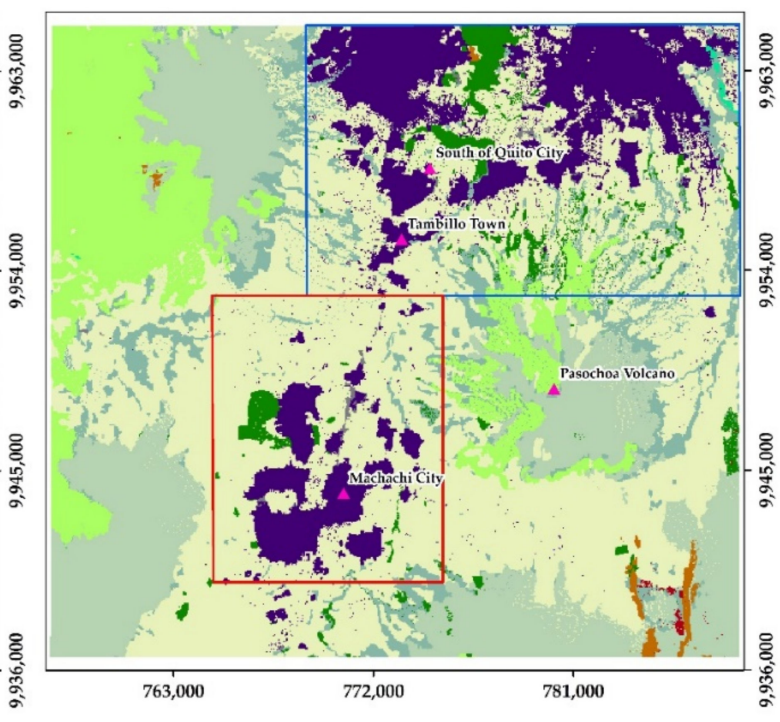

Simulated land use 5 years later

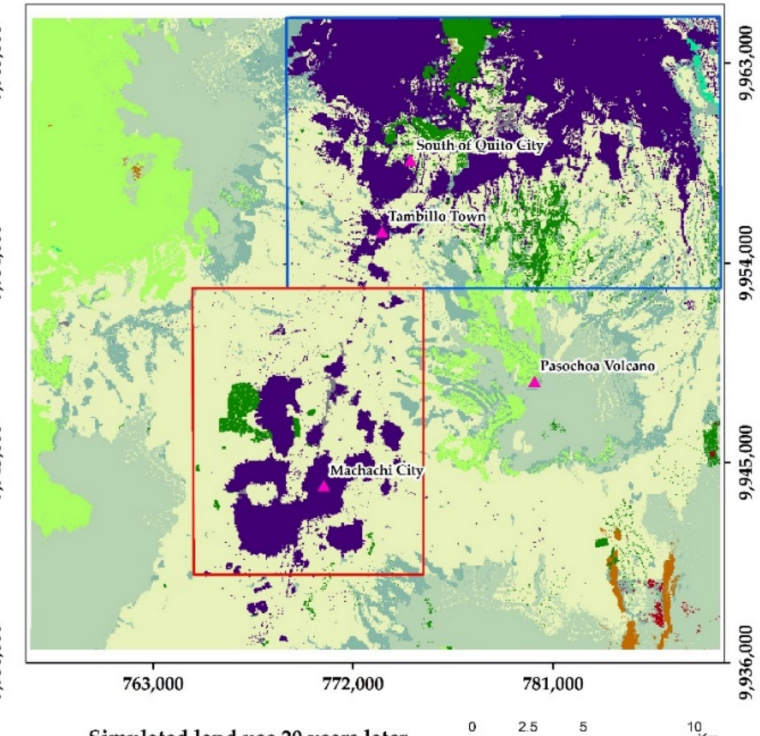

Simulated land use 20 years later

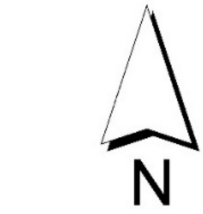

Projection: UTM, zone 17 south

Reference system WGS84

Figure 13. Top left: Actual land use map in 2018; top right: Simulated land use map in 2023; bottom left: Simulated land use map in 2028; bottom right: Simulated land use map in 2038. 
Table 6. Areas of land uses for 2023, 2028 and 2038 scenarios and their variation regarding 2018.

\begin{tabular}{|c|c|c|c|c|c|c|c|c|c|}
\hline \multirow[t]{2}{*}{$\begin{array}{l}\text { Land Use } \\
\text { Name. }\end{array}$} & & \multicolumn{2}{|c|}{$\begin{array}{c}2018 \\
\text { Actual Land Use }\end{array}$} & \multicolumn{2}{|c|}{2023 Scenario } & \multicolumn{2}{|c|}{2028 Scenario } & \multicolumn{2}{|c|}{2038 Scenario } \\
\hline & & $\begin{array}{l}\text { Area } \\
\left(\mathbf{k m}^{2}\right)\end{array}$ & $\begin{array}{c}\text { Area } \\
(\%)\end{array}$ & $\begin{array}{c}\text { Area } \\
\left(\mathrm{km}^{2}\right)\end{array}$ & $\begin{array}{c}\% \\
\text { Increment }\end{array}$ & $\begin{array}{c}\text { Area } \\
\left(\mathrm{km}^{2}\right)\end{array}$ & $\begin{array}{c}\% \\
\text { Increment }\end{array}$ & $\begin{array}{c}\text { Area } \\
\left(\mathrm{km}^{2}\right)\end{array}$ & $\begin{array}{c}\% \\
\text { Increment }\end{array}$ \\
\hline \multirow{3}{*}{$\begin{array}{c}\text { Forest } \\
\text { plantation }\end{array}$} & Study area & 23.64 & 2.68 & 23.23 & -1.73 & 23.21 & -1.82 & 22.97 & -2.83 \\
\hline & A.I. Quito & 14.31 & 6.04 & 15.07 & 5.31 & 16.13 & 12.72 & 16.60 & 16.00 \\
\hline & $\begin{array}{c}\text { A.I. } \\
\text { Machachi }\end{array}$ & 5.22 & 3.90 & 4.37 & -16.28 & 3.83 & -26.63 & 3.63 & -30.52 \\
\hline \multirow{4}{*}{$\begin{array}{l}\text { Areas with } \\
\text { no } \\
\text { vegetation } \\
\text { cover }\end{array}$} & Study area & 3.88 & 0.44 & 3.72 & -4.12 & 3.57 & -7.99 & 3.30 & -14.95 \\
\hline & A.I. Quito & 0.2 & 0.08 & 0.19 & -5.00 & 0.16 & -20.00 & 0.05 & -75.00 \\
\hline & $\begin{array}{c}\text { A.I. } \\
\text { Machachi }\end{array}$ & - & - & - & - & - & - & - & - \\
\hline & Study area & 66.13 & 7.50 & 66.76 & 0.95 & 67.65 & 2.30 & 68.82 & 4.07 \\
\hline \multirow{2}{*}{$\begin{array}{l}\text { Shrub } \\
\text { vegetation }\end{array}$} & A.I. Quito & 22.74 & 9.60 & 20.88 & -8.18 & 19.41 & -14.64 & 18.07 & -20.54 \\
\hline & $\begin{array}{c}\text { A.I. } \\
\text { Machachi }\end{array}$ & 3.94 & 2.94 & 4.58 & 16.24 & 4.74 & 20.30 & 4.10 & 4.06 \\
\hline \multirow{3}{*}{ Moorland } & Study area & 172.36 & 19.55 & 171.02 & -0.78 & 169.27 & -1.79 & 165.64 & -3.90 \\
\hline & $\begin{array}{l}\text { A.I. Quito } \\
\text { A.I. } \\
\text { Machachi }\end{array}$ & - & $\begin{array}{l}- \\
-\end{array}$ & - & 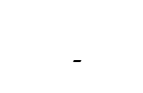 & $\begin{array}{l}- \\
-\end{array}$ & - & $\begin{array}{l}- \\
-\end{array}$ & - \\
\hline & Study area & 401.80 & 45.58 & 398.70 & -0.77 & 395.28 & -1.62 & 389.93 & -2.95 \\
\hline \multirow{3}{*}{$\begin{array}{l}\text { Agriculture } \\
\text { and } \\
\text { livestock }\end{array}$} & A.I. Quito & 120.56 & 50.90 & 115.46 & -4.23 & 109.40 & -9.26 & 97.92 & -18.78 \\
\hline & $\begin{array}{c}\text { A.I. } \\
\text { Machachi }\end{array}$ & 96.12 & 71.79 & 96.11 & -0.01 & 96.29 & 0.18 & 96.89 & 0.80 \\
\hline & Study area & 108.99 & 12.36 & 106.77 & -2.04 & 104.35 & -4.26 & 99.46 & -8.74 \\
\hline \multirow{3}{*}{$\begin{array}{l}\text { Native } \\
\text { forest }\end{array}$} & A.I. Quito & 4.66 & 1.97 & 4.46 & -4.29 & 4.17 & -10.52 & 3.47 & -25.54 \\
\hline & $\begin{array}{c}\text { A.I. } \\
\text { Machachi }\end{array}$ & 0.29 & 0.22 & 0.25 & -13.79 & 0.25 & -13.79 & 0.18 & -39.31 \\
\hline & $\begin{array}{l}\text { Study area } \\
\text { A.I. Quito }\end{array}$ & $\begin{array}{l}2.15 \\
1.21\end{array}$ & $\begin{array}{l}0.24 \\
0.51\end{array}$ & $\begin{array}{l}2.13 \\
1.18\end{array}$ & $\begin{array}{l}-0.93 \\
-2.48\end{array}$ & $\begin{array}{l}2.16 \\
1.19\end{array}$ & $\begin{array}{c}0.47 \\
-1.65\end{array}$ & $\begin{array}{l}2.20 \\
1.14\end{array}$ & $\begin{array}{c}2.33 \\
-5.79\end{array}$ \\
\hline \multirow{2}{*}{ Infrastructure } & $\begin{array}{c}\text { A.I. } \\
\text { Machachi }\end{array}$ & 0.83 & 0.62 & 0.85 & 2.41 & 0.86 & 3.61 & 0.95 & 14.22 \\
\hline & Study area & 0.62 & 0.07 & 0.62 & 0.00 & 0.62 & 0.00 & 0.62 & 0.00 \\
\hline \multirow[t]{3}{*}{$\begin{array}{c}\text { Natural } \\
\text { water } \\
\text { bodies }\end{array}$} & A.I. Quito & 0.6 & 0.25 & 0.6 & 0.00 & 0.60 & 0.00 & 0.60 & 0.00 \\
\hline & $\begin{array}{c}\text { A.I. } \\
\text { Machachi }\end{array}$ & - & - & - & - & - & - & - & - \\
\hline & Study area & 0.70 & 0.08 & 0.71 & 1.43 & 0.72 & 2.86 & 0.77 & 10.00 \\
\hline \multirow[t]{3}{*}{$\begin{array}{l}\text { Herbaceous } \\
\text { vegetation }\end{array}$} & A.I. Quito & - & - & - & - & - & - & - & - \\
\hline & $\begin{array}{c}\text { A.I. } \\
\text { Machachi }\end{array}$ & - & - & - & - & - & - & - & - \\
\hline & Study area & 101.34 & 11.49 & 107.90 & 6.47 & 114.68 & 13.16 & 127.71 & 26.02 \\
\hline \multirow[t]{2}{*}{ Urban area } & A.I. Quito & 72.57 & 30.64 & 78.9 & 8.72 & 85.53 & 17.86 & 98.35 & 35.52 \\
\hline & $\begin{array}{c}\text { A.I. } \\
\text { Machachi }\end{array}$ & 27.49 & 20.53 & 27.73 & 0.87 & 27.91 & 1.53 & 28.15 & 2.39 \\
\hline Total $\left(\mathrm{km}^{2}\right)$ & & \multicolumn{2}{|c|}{ Study area: 881.61} & \multicolumn{3}{|c|}{ Quito: 236.85} & \multicolumn{3}{|c|}{ Machachi: 133.89} \\
\hline
\end{tabular}




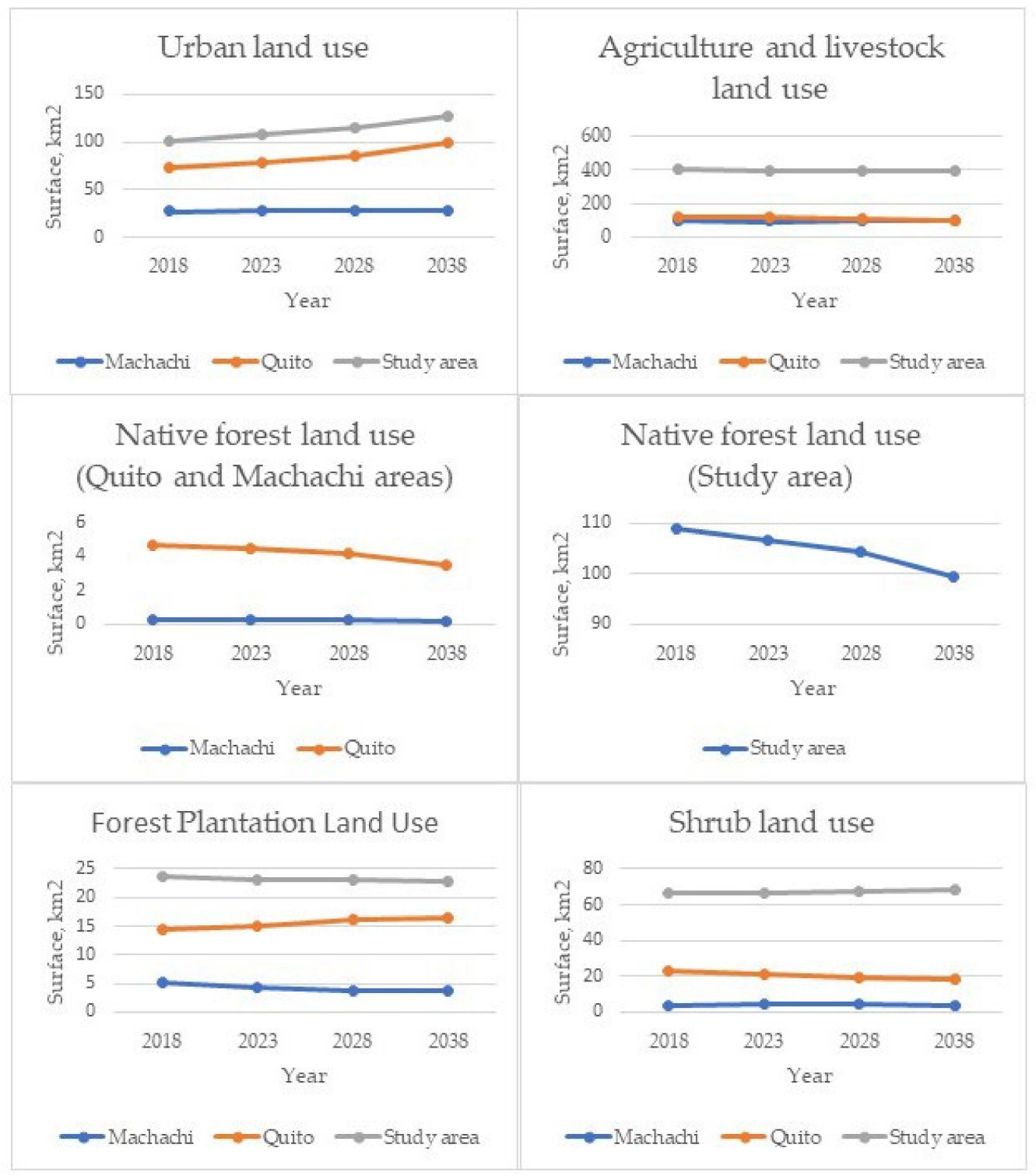

Figure 14. Expected trends in the changes in key land uses in the areas of Quito, Machachi and Alóag, and in the whole study area. Top left: Urban land use; top right: Agriculture and livestock land use; center left: Native forest land use (Quito, Machachi and Alóag areas); center right: Native forest land use (study area); bottom left: Forest plantation land use; bottom right: Shrub land use.

The results point to two areas of growth in Quito: Los Chillos Valley (Rumiñahui Canton) and Conocoto (Quito Canton). The main driving factors are socioeconomic. The factor driving the growth of Los Chillos Valley is the internal migratory movements from the city to the valley, swallowing up small towns in the rural periphery, and the movement of poor people from the city center to the slopes of the Ilalo volcano.

On the other hand, the main driving factors in natural land use changes are deforestation due to an increase in agriculture and livestock land use and illegal logging [85].

Forest plantations are predicted to decline by $1 \mathrm{~km}^{2}$ (see Figure 14) in 2038; however, in the Quito area, they are expected to increase by $16 \%$ by $2038: 2.3 \mathrm{~km}^{2}$ compared to their area in 2018. However, the Machachi and Alóag area will suffer a loss of plantations of $1 \mathrm{~km}^{2}$ in 2023 and another approximately $1 \mathrm{~km}^{2}$ between 2028 and 2038. This land use will be replaced by agriculture and livestock land use.

The area of shrub land use will increase in the whole study area as the native forest is substituted by shrub vegetation. However, part of the urban growth in the Quito area is 
expected to be in shrub land use. Figure 14 shows a slight downward trend in this area for this land use.

The agriculture and livestock land use will increase in some areas, especially in the Machachi Valley, but decrease in the Quito area, with an overall balance of $-3,-3$ and $-6 \mathrm{~km}^{2}$ in 2023, 2028 and 2038, respectively.

Finally, the infrastructure land use occupies a small area (see Table 5), which will decrease by up to $5 \%$ in the Quito area.

\section{Discussion}

The projection of land use changes in 2023, 2018 and 2038 shows that the extent of urban expansion relative to other land use changes will vary markedly in the next years, maintaining the same trend as in recent decades [19]. Our analysis indicates that this growth will accelerate in 2028 in Quito but remain stable in the Machachi Valley. This is due to the reduction in the share of population living in the center, due to lower housing prices in the outskirts [86]. This growth on the fringe of the city is a characteristic shared by all Latin American cities [87]. The estimations of the distribution of land uses from 2023 to 2038 in the study area show that the new urban zones on the fringe of the city will become consolidated over time. A similar pattern can be seen in Andean cities such as Bogota and Cuzco [87]. The main reason is that informal residents are motivated to densify in order to access services to enhance their living standards [88].

The results (see Figures 2 and 13) show two areas of growth in Quito: Los Chillos Valley (Rumiñahui Canton) and Conocoto (Quito Canton). Over the last four decades, the trend towards urban dispersion in the valley territories has progressively swallowed up small towns in the rural periphery into the metropolitan system, forming dormitory towns for the city of Quito [84]. According to our results, the locality of San Rafael will grow until it merges with the locality of Amaguaña, which in turn will spread southwards, reaching the southern limit of Quito up to the town of Tambillo. Tambillo is one of the oldest settlements in the country, a crossroads that has traditionally served as a resting place for travelers and today marks the start of the 28A motorway and its intersection with the Pan-American Highway.

Since the 1980s, the creation of irregular settlements in the valley and on the slopes of the Ilalo volcano has intensified. Although government institutions provide basic services and infrastructure such as paving, drinking water, sewage and mortgage guarantees, the influence of the land market on the spread of these settlements has not yet been considered by the administration. These settlements have increased the deforestation of native forest and the construction of unhealthy and highly vulnerable urban environments $[89,90]$. It is also an area of volcanic risk due to its proximity to the Cotopaxi volcano-which has been very active in recent years-as the lava flow would engulf the Los Chillos Valley [20,91]. The practice of building on steep slopes increases the risk of landslides in this type of settlements, as occurs in other cities in the Andes such as Bogota, due to the quality of the slope constructions and the variability in precipitation [88]. According to the results, these problems will increase in the near future as irregular settlements keep spreading.

The area of the Conocoto plateau (Metropolitan District of Quito) (see Figure 13) is predicted to undergo a major urban spread that will continue in a more dispersed way towards the south of Conocoto. Factors such as its favorable climate make it very attractive for urban expansion, especially for premium residences. This result coincides with Carrión's estimation for 2030 [92].

Native forests will also be affected despite the fact that their conservation is mandated by the 2004 law on the conservation of forestry, wildlife and natural areas: "The afforestation and reforestation of forest lands shall be declared obligatory and in the public interest, prohibiting their use for other purposes". The decrease in native forest impacts environmental sustainability since this land use plays an important role in the ecological balance. This type of forest will gradually degrade into shrub land use, mainly on the slopes of the Pasochoa volcano (see Figures 1 and 13), except on the northern slope (belonging 
to the Quito area), where plantations will replace a small part of the native forest felled by the inhabitants of this area [88]. Figure 13 (center) shows how the increasing trend of the native forest in the whole study area is much more pronounced than in the areas of Quito, Machachi and Alóag. This trend of native forest substitution differs from the native forest recovery in the hinterland of Bogotá (Colombia) [22]. Quito's forest trend is like La Paz's trend where timber exploitation enables agriculture penetration and prevents native forest recovery [93]. Road infrastructure construction is a common thread for native forests in these Andean cities [22,93]. The agriculture and livestock land use will increase in some areas, especially in the Machachi Valley due to the high demand for these products in Quito [56].

Infrastructure land use will decrease by up to 5\% in the Quito area due to the growth in urban land use. As in previous studies, the expansion of urban land uses usually occurs at the expense of these latter land uses [8,94,95].

The results from the trends and scenarios reinforce the earlier findings on urban growth trends in Quito [19,96]. Salazar et al. [26] predicted an important loss of vegetated areas for 2050 since the Ecuadorian Space Institute's proposals allow urban development in areas of forests, volcanic risk and agricultural production. These policies go against all international agreements on sustainability, biodiversity and climate change and the current Ecuadorian legislation.

Finally, the validation measures show that overall land cover classification accuracy was strong. The value of similarity, $72 \%$, is satisfactory for model validation [81,82], and the kappa measures, all of them higher than 0.7 , indicate that there is a substantial overall ability of the CA-MC model to predict land use changes $[80,97]$.

\section{Conclusions}

Major cities in the Andes and in Latin America in general will increase their population sharply in the coming years. The results of this research identify some of the social, infrastructure and environmental challenges that will need to be tackled by policy makers in the near future. As a case of application, this research represents one of the first investigations to use cellular automata to analyze and estimate the land use scenario based on simulation results in the south of Quito and the Machachi Valley. Our model forecasts the location of land uses in 2023, 2028 and 2028 from the real land use map of 2018. The results of the simulations warn of an environmental and socioeconomic challenge in the future due to runaway urbanization and the disappearance of the native forest and plantations in some mountainous areas. The temporal mapping indicates that the urban development template is continuously expanding and radiating outward from Quito, under regulated growth in Conocoto, but in the form of illegal or irregular settlements in Los Chillos Valley. The modelling results indicate that the city's growth takes the form of urban consolidation, in areas of irregular settlements, to ensure access to roads and services are mainly dispersed in legal settlements in Conocoto. This characteristic can be of use for automatic classifications of urban growth models.

However, in cities that are more distant from Quito such as Machachi and Alóag, the area dedicated to urban land use will remain stable; the main change will be the substitution of forest plantations by agriculture and livestock land uses due to the high demand for food from Quito.

One key environmental issue is the native forest areas in the Andes, where the tendency of the forest to disappear will persist in the coming years and be substituted by regressive shrub forest despite the laws protecting natural resources. The application of protective policies is the key to halting this deforestation.

Author Contributions: Conceptualization, R.U.-E. and S.M.-F.; methodology, R.U.-E. and S.M.-F.; data collection, R.U.-E. formal analysis, R.U.-E. and S.M.-F.; writing-original draft, R.U.-E. and S.M.-F.; writing-review and editing, R.U.-E. and S.M.-F. All authors have read and agreed to the published version of the manuscript. 
Funding: This research received no external funding.

Institutional Review Board Statement: Not applicable.

Informed Consent Statement: Not applicable.

Data Availability Statement: No new data were created or analyzed in this study. Data sharing is not applicable to this article.

Acknowledgments: We would like to thank the academic editor and the reviewers for their suggestions and comments for improving this work.

Conflicts of Interest: The authors declare no conflict of interest.

\section{References}

1. Schulp, C.J.E.; Levers, C.; Kuemmerle, T.; Tieskens, K.F.; Verburg, P.H. Mapping and modelling past and future land use change in Europe's cultural landscapes. Land Use Policy 2019, 80, 332-344. [CrossRef]

2. Department of Economic and Social Affairs. World Urbanization Prospects: The 2018 Revision: Final Report; United Nations: New York, NY, USA, 2019; p. 126.

3. Department of Economic and Social Affairs. World Urbanization Prospects. The 2011 Revision: Final Report; United Nations: New York, NY, USA, 2012; p. 318.

4. Seto, K.C.; Güneralp, B.; Hutyra, L.R. Global forecasts of urban expansion to 2030 and direct impacts on biodiversity and carbon pools. Proc. Natl. Acad. Sci. USA 2012, 109, 16083-16088. [CrossRef]

5. Angel, S.; Parent, J.; Civco, D.L.; Blei, A.; Potere, D. The dimensions of global urban expansion: Estimates and projections for all countries, 2000-2050. Prog. Plan. 2011, 75, 53-107. [CrossRef]

6. Van Ginkel, H. Urban future. Nature 2008, 456, 32-33. [CrossRef]

7. Mandelas, E.A.; HAtzichristos, T.; Prastacos, P.A. Fuzzy cellular automata based Shell for modelling Urban Growth: A Pilot Application in Mesogia Area. In Proceedings of the 10th AGILE International Conference on Geographic Information Science 2007, Aalborg, Denmark, 8-11 May 2007; Monica Wachowicz, M., Bodum, L., Eds.; Association of Geographic Information Laboratories in Europe: Aalborg, Denmark, 2007.

8. Al-Darwish, Y.; Ayad, H.; Taha, D.; Saadallah, D. Predicting the future urban growth and its impacts on the surrounding environment using urban simulation models: Case study of Ibb city, Yemen. Alex. Eng. J. 2018, 57, 2887-2895. [CrossRef]

9. McKinney, M.L. Effects of urbanization on species richness: A review of plants and animals. Urban Ecosyst. 2008, 11, 161-176. [CrossRef]

10. McDonald, R.I.; Kareiva, P.; Forman, R.T.T. The implications of current and future urbanization for global protected areas and biodiversity conservation. Biol. Conserv. 2008, 141, 1695-1703. [CrossRef]

11. Pimm, S.L.; Raven, P. Biodiversity. Extinction by numbers. Nature 2000, 403, 843-845. [CrossRef]

12. Song, X.P.; Hansen, M.C.; Stehman, S.V.; Potapov, P.V.; Tyukavina, A.; Vermote, E.F.; Townshend, J.R. Global land change from 1982 to 2016. Nature 2018, 560, 639-643. [CrossRef]

13. Hutyra, L.R.; Byungman, Y.; Hepinstall-Cymerman, J.; Alberti, M. Carbon consequences of land cover change and expansion of urban lands: A case study in the Seattle metropolitan region. Landsc. Urban Plan 2011, 103, 83-93. [CrossRef]

14. Fusco Girard, L.; Cerreta, M.; De Toro, P.; Forte, F. The Human Sustainable City: Values, Approaches and Evaluative Tools. In Sustainable Urban Development, 1st ed.; Mark Deakin, M., Mitchell, G., Nijkamp, P., Vreeker, R., Eds.; Taylor and Francis Group: London, UK, 2007; Volume 2, pp. 65-93.

15. IPBES. Ipbes global assessment on biodiversity and ecosystem services. In Intergovernmental Science-Policy Platform on Biodiversity and Ecosystem Services; IPBES: Paris, France, 2019.

16. Thapa, R.; Murayama, Y. Scenario based urban growth allocation in Kathmandu Valley, Nepal. Landsc. Urban Plan 2012, 105, 140-148. [CrossRef]

17. Lattes, A.E.; Rodríguez, J.; Villa, M. Population dynamics and urbanization in Latin America: Concepts and data limitations. In New Forms of Urbanization: Beyond the Urban-Rural Dichotomy, 1st ed.; Champion, T., Ed.; Routledge: London, UK, 2004; pp. 85-107. [CrossRef]

18. United Nations Human Settlements Program (UN_HABITAT). World Cities Report 2020 The Value of Sustainable Urbanization; UN-Habitat: New York, NY, USA, 2020; p. 418.

19. Carrión, F.; Erazo Espinosa, J. La forma urbana de Quito: Una historia de centros y periferias. Bull. Inst. Franç. Etudes Andin. 2012, 41. [CrossRef]

20. Pinos Arévalo, N.J. Prospectiva del uso de suelo y cobertura vegetal en el ordenamiento territorial一Caso cantón Cuenca. Estoa 2016, 5. [CrossRef]

21. Burgess, R.; Jenks, M. Compact Cities: Sustainable Urban Forms for Developing Countries, 1st ed.; Spon Press: London, UK, 2000.

22. Calbi, M.; Clerici, N.; Borsch, T.; Brokamp, G. Reconstructing Long Term High Andean Forest Dynamics Using Historical Aerial Imagery: A Case Study in Colombia. Forests 2020, 11, 788. [CrossRef] 
23. Taubenböck, H.; Esch, T.; Felbier, A.; Wiesner, M.; Roth, A.; Dech, A. Monitoring urbanization in mega cities from space. Remote Sens. Environ. 2012, 117, 162-176. [CrossRef]

24. Wu, Y.; Zhang, X.; Skitemore, M.; Song, Y.; Hui, E.C.M. Industrial land price and its impact on urban growth: A Chinese case study. Land Use Policy 2014, 36, 199-209. [CrossRef]

25. Kong, F.; Yin, H.; Nakagoshi, N.; James, P. Simulating urban growth processes incorporating a potential model with spatial metrics. Ecol. Indic. 2012, 20, 82-91. [CrossRef]

26. Salazar, E.; Henríquez, C.; Sliuzas, R.; Qüense, J. Evaluating Spatial Scenarios for Sustainable Development in Quito, Ecuador. ISPRS Int. J. Geo-Inf. 2020, 9, 141. [CrossRef]

27. Couclelis, H. Where has the Future Gone? Rethinking the Role of Integrated Land-Use Models in Spatial Planning. Environ. Plann. A 2005, 37, 1353-1371. [CrossRef]

28. Schlüter, M.; Baeza-Castro, A.; Dressler, G.; Frank, K.; Groeneveld, J.; Jager, W.; Janssen, M.; McAllister, R.R.J.; Müller, B.; Orach, K.; et al. A framework for mapping and comparing behavioural theories in models of social-ecological systems. Ecol. Econ. 2017, 131, 21-35. [CrossRef]

29. Theobald, D. Landscape patterns of exurban growth in the USA from 1980 to 2020. Ecol. Soc. 2005, 10, 34. [CrossRef]

30. Verburg, P.H.; Overmars, K.P. Dynamic simulation of land-use change trajectories with the clue-s model. In Modelling Land-Use Change: Progress and Applications; Koomen, E., Stillwell, J., Bakema, A., Scholten, H.J., Eds.; Springer: Dordrecht, The Netherlands, 2007; pp. 321-337.

31. Jantz, C.A.; Goetz, S.J.; Shelley, M.K. Using the SLEUTH urban growth model to simulate the impacts of future policy scenarios on urban land use in the Baltimore-Washington metropolitan area. Environ. Plan B 2004, 31, 251-271. [CrossRef]

32. Sloan, S.; Pelletier, J. How accurately may we project tropical forest-cover change? A validation of a forward-looking baseline for REDD. Global Environ. Chang. 2012, 22, 440-453. [CrossRef]

33. Sleeter, M.; Liu, J.; Daniel, C.; Frid, L.; Zhu, Z. An integrated approach to modeling changes in land use, land cover, and disturbance and their impact on ecosystem carbon dynamics: A case study in the Sierra Nevada Mountains of California AIMS. Environ. Sci. 2015, 2, 577-606. [CrossRef]

34. Reyes-Gómez, D.A. Descripción y Aplicaciones de los Autómatas Celulares. Master's Thesis, Universidad Autónoma de Puebla, Puebla, Mexico, 25 August 2011.

35. Allen, P.M. Cities and regions as evolutionary complex systems. Geogr. Syst. 1997, 4, 103-130.

36. Gharbia, S.S.; Alfatah, S.A.; Gill, L.; Johnston, P.; Pilla, F. Land use scenarios and projections simulation using an integrated GIS cellular automata algorithm. Model. Earth Syst. Environ. 2016, 2, 151. [CrossRef]

37. Zhang, Q.; Ban, Y.; Liu, J.; Hu, Y. Simulation and analysis of urban growth scenarios for the Greater Shanghai Area, China. Comp. Environ. Urb. Syst. 2011, 35, 126-139. [CrossRef]

38. Pahlavani, P.; Askarian Omran, H.; Bigdeli, B. A multiple land use change model based on artificial neural network, markov chain, and multi objective land allocation. Earth Obs. Geomat. Eng. 2017, 1, 82-99.

39. Ozturk, D. Urban growth simulation of Atakum (Samsun, Turkey) using cellular automata-markov chain and multi-layer perceptron-Markov chain models. Remote Sens. 2015, 7, 5918-5950. [CrossRef]

40. Morais Ferreira, B.; Silveira Soares-Filho, B.; Magno Quintão Pereira, F. The Dinamica EGO virtual machine. Sci. Comput. Program. 2019, 173, 3-20. [CrossRef]

41. Soares-Filho, B.S.; Moutinho, P.; Nepstad, D.; Anderson, A.; Rodrigues, H.; Garcia, R.; Maretti, C. Role of Brazilian Amazon protected areas in climate change mitigation. Proc. Natl. Acad. Sci. USA 2010, 107, 10821-10826. [CrossRef]

42. Espinoza-Mendoza, V.E. DINAMICA EGO: Una herramienta gratuita para modelar y brindar soporte en el análisis de CCUS. Bol. Col. Geógrafos Perú 2016, 3, 1-13.

43. Mas, J.F.; Kolb, M.; Paegelow, M.; Camacho, M.T.; Houet, T. Inductive pattern-based land use/cover change models: A comparison of four software packages. Environ. Modell. Softw. 2014, 51, 94-111. [CrossRef]

44. Maeda, E.; Almeida, C.M.; Carvalho, A.; Formaggio, A.; Shimabukuro, Y.; Pellikka, P. Dynamic modeling of forest conversion: Simulation of past and future scenarios of rural activities expansion in the fringes of the Xingu National Park, Brazilian Amazon. Int. J. Appl. Earth Obs. 2011, 13, 435-446. [CrossRef]

45. Mas, J.F.; Flamenco, A. Modelación de los cambios de coberturas/uso del suelo en una región tropical de México. GeoTrópico 2011, 5, 1-24. Available online: http:/ / www.geotropico.org/NS_5_1_Mas-Flamenco.pdf. (accessed on 25 March 2021).

46. Pérez, A.; Mas, J.F.; Ligmann, A. Comparing two approaches to land/use cover change modeling and their implications for the assessment of biodiversity loss in a deciduous tropical forest. Environ. Modell. Softw. 2012, 29, 11-23. [CrossRef]

47. Bahadur, R.; Murayama, Y. Urban growth modeling of Kathmandu metropolitan region, Nepal. Comp. Env. Urb. Sys. 2011, 35, 25-34. [CrossRef]

48. Godoy, M.M.G.; Soares-Filho, B.S. Modelling intraurban dynamics in the Savassi neighbourhood, Belo Horizonte city, Brazil. In Modelling Environmental Dynamics, 1st ed.; Paegelow, M., Camacho, M.T., Eds.; Springer: Berlin/Heidelberg, Germany, 2008; pp. 319-338.

49. Cheng, L.; Liu, M.; Zhan, J. Land use scenario simulation of mountainous districts based on Dinamica EGO model. J. Mt. Sci. 2020, 17, 289-303. [CrossRef]

50. Pathirana, A.; Hailu, B.D.; Veerbeek, W.; Zevenbergen, C.; Banda, A.T. Impact of urban growth-driven land use change on microclimate and extreme precipitation. A sensitivity study. Atmos. Res. 2014, 138, 59-72. [CrossRef] 
51. Josse, C.; Cuesta, F.; Navarro, G.; Barrena, V.; Cabrera, E.; Chacón-Moreno, E.; Ferreira, W.; Peralvo, M.; Saito, A. Ecosistemas de los Andes del Norte y Centro. Bolivia, Colombia, Ecuador, Perú y Venezuela, 1st ed.; Secretaría General de la Comunidad Andina: Lima, Peru, 2009; p. 100.

52. Consejo de planificación del cantón Mejía. Actualización del Plan de Desarrollo Y Ordenamiento Territorial 2019-2023; Gobierno Autónomo Descentralizado Municipal del Cantón Mejía: Machachi, Ecuador, 2019; p. 569.

53. Ministerio de Agricultura, Ganadería, Acuacultura y Pesca de Ecuador; Ministerio del Ambiente del Ecuador, Secretaría Nacional de Planificación y Desarrollo. Mapa de Cobertura y Uso de la Tierra; Ministerio del Ambiente de Ecuador: Machachi, Ecuador, 2014.

54. Dirección de Estadísticas Agropecuarias y Ambientales. Boletín Técnico: Encuesta de Superficie y Producción Agropecuaria Continua (ESPAC); Instituto Nacional de Estadística y Censos: Quito, Ecuador, 2020; p. 15.

55. Equipo Técnico de Análisis del Censo de Población y Vivienda. Resultados de Censos de Población y Vivienda del Ecuador 2010. Fascículo de la Provincia de Pichincha; Instituto Nacional de estadística y Censos: Quito, Ecuador, 2010; p. 15.

56. Escobar, S. Caracterización del Paisaje del Valle de Machachi (Ecuador), y Análisis de su Evolución Reciente (1940-2015). Doctoral Thesis, Universidad de Barcelona, Barcelona, Spain, 26 September 2018.

57. Advanced Spaceborne Thermal Emission and Reflection Radiometer, California Institute of Technology, NASA. Available online: https: / / asterweb.jpl.nasa.gov / index.asp (accessed on 13 July 2021).

58. Ministerio del Ambiente. Linea Base de Deforestación del Ecuador Continental; Ministerio de Medio Ambiente: Quito, Ecuador, 2012; p. 32.

59. Olofsson, P.; Foody, G.M.; Stehman, S.V.; Woodcock, C.E. Making better use of accuracy data in land change studies: Estimating accuracy and area and quantifying uncertainty using stratified estimation. Remote Sens. Environ. 2013, 129, 122-131. [CrossRef]

60. Ministerio de Medio Ambiente. Informe sobre la Reducción de Emisiones por Deforestación en el Ecuador para Pagos Basados en Resultados de REDD+ Periodo 2017-2018; Ministerio de Medio Ambiente: Quito, Ecuador, 2019; p. 68.

61. Instituto Espacial Ecuatoriano. Proyecto de Generación de Geoinformación para la Gestión del Territorio a Nivel Nacional Escala 1: 25 000; Ministerio de Defensa Nacional: Quito, Ecuador, 2012.

62. Instituto Espacial Ecuatoriano. Memoria Técnica Cantón Mejía, Proyecto: "Generación de Geo Información para la Gestión del Territorio a Nivel Nacional Escala 1: 25 000" Evaluación de las Tierras por su Capacidad de Uso; Ministerio de Defensa Nacional: Quito, Ecuador, 2013 ; p. 63.

63. Instituto Espacial Ecuatoriano. Memoria Técnica Cantón Mejía, Proyecto: “Generación de Geo Información para la Gestión del Territorio a Nivel Nacional Escala 1: 25 000". Infraestructuras y Servicios; Ministerio de Defensa Nacional: Quito, Ecuador, 2013 ; p. 41.

64. Instituto Espacial Ecuatoriano. Memoria Técnica Cantón Mejí, Proyecto: “Generación de Geo Información para la Gestión del Territorio a Nivel Nacional Escala 1: 25 000". Análisis de Amenaza por Tipo de Movimiento en Masa; Ministerio de Defensa Nacional: Quito, Ecuador, 2013; p. 57.

65. Instituto Espacial Ecuatoriano. Memoria Técnica Cantón Mejía, Proyecto: “Generación de Geo Información para la Gestión del Territorio a Nivel Nacional Escala 1: 25 000". Socioeconómico y Cultural; Ministerio de Defensa Nacional: Quito, Ecuador, 2013 ; p. 57.

66. Rykiel, E.J. Testing ecological models: The meaning of validation. Ecol. Modell. 1996, 90, 229-244. [CrossRef]

67. Mondal, B.; Das, D.N.; Bhatta, B. Integrating cellular automata and Markov techniques to generate urban development potential surface: A study on Kolkata agglomeration. Geocarto Int. 2017, 32, 401-419. [CrossRef]

68. Ghosh, P.; Mukhopadhyay, A.; Chanda, A.; Mondal, P.; Akhand, A.; Mukherjee, S.; Nayak, S.K.; Ghosh, S.; Mitra, D.; Ghosh, T.; et al. Application of Cellular automata and Markov-chain model in geospatial environmental modeling. A review. Remote Sens. Appl. Soc. Environ. 2017, 5, 64-77. [CrossRef]

69. Weed, D.L. Weight of Evidence: A Review of Concept and Methods. Risk Anal. 2005, 25, 1545-1557. [CrossRef]

70. Goodacre, A.K.; Bonham-Carter, G.F.; Agterberg, F.P.; Wright, D.F. A statistical analysis of the spatial association of seismicity with drainage patterns and magnetic anomalies in western Quebec. Tectonophysics 1993, 217, 285-305. [CrossRef]

71. Kotrlik, J.W.; Williams, H.A.; Jabor, M.K. Reporting and Interpreting Effect Size in Quantitative. J. Agric. Educ. 2011, 52, 132-142. [CrossRef]

72. Rea, L.M.; Parker, R.A. Designing and Conducting Survey Research, 4th ed.; Jossey-Bass: San Francisco, CA, USA, $1992 ;$ p. 352.

73. Rodrigues, H.O.; Soares-Filho, B.S.; Costa, W.L.D.S. Dinamica EGO, uma plataforma para modelagem de sistemas ambientais. In Proceedings of the XIII Simpósio Brasileiro de Sensoriamento Remoto, Florianpólis, Brazil, 21-26 April 2007.

74. Joint Research Centre. Modelling Deforestation Processes-A review. Research Report No.1; European Commission/Institute for Remote Sensing Applications, and European Space Agency: Luxembourg, 1994; p. 113.

75. Hagen-Zanker, A. An improved Fuzzy Kappa statistic that accounts for spatial autocorrelation. Int. J. Geogr. Inf. Sci. 2009, 19, 831-857. [CrossRef]

76. Pontius, R.G. Statistical methods to partition effects of quantity and location during comparison of categorical maps at multiple resolutions. Photogramm. Eng. Remote Sens. 2002, 68, 1041-1049. Available online: https://www.asprs.org/wp-content/uploads/ pers /2002journal/october/2002_oct_1041-1049.pdf (accessed on 13 July 2021).

77. Ulloa, R.; Lalama, E. Geopronósticos de asentamientos con construcciones civiles en las periferias de la ciudad basado en autómatas celulares: Caso zona norte-Calderón. Rev. Geospacial 2018, 15, 45-59. [CrossRef]

78. Pontius, R.G., Jr. Quantification error versus location error in comparison of categorical maps. Photogramm. Eng. Remote Sens. 2000, 66, 1011-1016. 
79. Rimal, B.; Sloan, S.; Keshtkar, H.; Sharma, R.; Rijal, S.; Shrestha, U.B. Patterns of Historical and Future Urban Expansion in Nepal. Remote Sens. 2020, 12, 628. [CrossRef]

80. Leta, M.K.; Demissie, T.A.; Tränckner, J. Modeling and Prediction of Land Use Land Cover Change Dynamics Based on Land Change Modeler (LCM) in Nashe Watershed, Upper Blue Nile Basin, Ethiopia. Sustainability 2021, 13, 3740. [CrossRef]

81. Hagen, A. Fuzzy set approach to assessing similarity of categorical maps. Int. J. Geogr. Inf. Sci. 2003, 17, 235-249. [CrossRef]

82. Piontekowski, V.; da Silva, S.; Mendoza, E.; de Souza Costa, W.; Ribeiro, F.; Ribeiro, C. Modelagem do desmatamento para o Estado do Acre utilizando o programa DinamicaEGO. In Proceedings of the 4th Simpósio de Geotecnologias no Pantanal, Bonito, Brasil, 20-24 October 2012.

83. Costa Roriz, P.A.; Miho Yanai, A.; Martin, P. Deforestation and Carbon Loss in Southwest Amazonia: Impact of Brazil's Revised Forest Code. Environ. Manag. 2017, 60, 367-382. [CrossRef] [PubMed]

84. Mejía Salazar, M.; Páliz, C.F. El territorio periurbano de la ciudad de Quito: Expansión urbana, cambio de la morfología y valor del suelo. Caso de estudio "valle de Los Chillos", Distrito Metropolitano de Quito, Ecuador. EIDOs. Rev. Cient. Urban. Arquit. 2018, 11, 1-26. [CrossRef]

85. Corporación de Manejo Forestal Sustentable. Planificación Estratégica de los Bosques Nativos de Ecuador 2007-2012; Corporación de Promoción de Exportaciones: Quito, Ecuador, 2007; p. 141.

86. Sanguinetti, P.; Vargas, J. Urban Growth and Access to Opportunities: A Challenge for Latin America; Corporación Andina de Fomento: Bogota, Colombia, 2018; p. 120.

87. Inostroza, L. Informal urban development in Latin American urban peripheries. Spatial assessment in Bogotá, Lima and Santiago de Chile. Landsc. Urban. Plan 2017, 165, 267-279. [CrossRef]

88. Puente-Sotomayor, F.; Egas, A.; Teller, J. Land policies for landslide risk reduction in Andean cities. Habitat Int. 2021, 107, 102298. [CrossRef]

89. Gómez-Salazar, A.; Cuvi, N. Informal settlements and environment in Quito. Áreas. Rev. Int. Cienc. Soc. 2016, 35, 101-119.

90. Mena, A.P. Regularización de los Asentamientos Informales en Quito: Análisis de las Políticas Públicas, FLACSO Ecuador. Master's Thesis, Facultad Latinoamericana de Ciencias Sociales, Sede, Ecuador, July 2010.

91. Robert, J.; D’Ercole, R.; Pigeon, P.; Serrano, T. Complejidad, incertidumbre y vulnerabilidad: El riesgo asociado al volcán Cotopaxi en el Valle de Los Chillos (Quito, Ecuador). Bull. Inst. Franç. Etudes Andin. 2009, 38, 709-733. [CrossRef]

92. Carrión Cueva, M.A. Análisis de la Dinámica de Crecimiento Urbano en la Cabecera Parroquial de Conocoto, en el Periodo de Estudio 2001 a 2010 y Escenario Tendencial al 2030. Ph.D. Thesis, Pontificia Universidad Católica del Ecuador, Facultad de Ciencias Humanas, Quito, Ecuador, 2020.

93. Müller, R.; Pacheco, P.; Montero, J.C. The Context of Deforestation and Forest Degradation in Bolivia Drivers, Agents, and Institutions; Center for International Forestry Research: Bogor, Indonesia, 2014; p. 92.

94. Jieying, X.; Yanjun, S.; Jingfeng, G.; Ryutaro, T.; Changyuan, T.; Yanqing, L.; Zhiying, H. Evaluating urban expansion and land use change in Shijiazhuang, China, by using GIS and remote sensing. Landsc. Urban Plan. 2006, 75, 69-80. [CrossRef]

95. Li, F.; Xie, Z.; Clarke, K.C.; Li, M.; Chen, H.; Liang, J.; Chen, Z. An agent-based procedure with an embedded agent learning model for residential land growth simulation: The case study of Nanjing, China, Cities. Land Use policy 2020, 88, 155-165. [CrossRef]

96. Durán, G.; Martí, M.; Mérida, J. Crecimiento, segregación y mecanismos de desplazamiento en el periurbano de Quito. Íconos Rev. Cienc. Soc. 2016, 56, 123. [CrossRef]

97. Viera, A.J.; Garrett, J.M. Understanding interobserver agreement: The kappa statistic. Fam. Med. 2005, 37, 360-363. [PubMed] 